\title{
The Implementation of Illustrative Techniques in Teaching Children and Young People about Emotions
}

Zvonimir Parać', Katarina Kružičević2 , Gabrijela Ratkajec Gašević3 , Željko Ključević 4 and Mirela Grbić ${ }^{4}$

'Third Grammar School Osijek

${ }^{2}$ Center for Children, Young people and Family Duga in Solin

${ }^{3}$ University of Zagreb, Faculty of Education and Rehabilitation Sciences

${ }^{4}$ Service of Mental Health, Public Health Institute, Split-Dalmatia County

\section{Abstract}

The comic book art technique is rarely analyzed as an expressive technique within the field of mental health and prevention of behavioral problems of children and young people. That is why the aim of this study is directed towards analyzing the potentials of comic book art as an expressive technique. The evaluation results of the "Mostly Sunny" project were used, and qualitative research methods were applied. The data were obtained through evaluation questionnaires, and group conversations were analyzed on a descriptive level and through thematic framework analysis. The quantitative and qualitative indicators show coherence in the impressions of the analyzed materials. Through thematic framework analysis, where three subjects were defined beforehand (the usefulness of the materials, understanding the applicability of the materials, understanding the comic's messages), 21 dimensions were recognized. Adolescents are known for their difficulties in verbalizing their thoughts and emotions. Various approaches have been used in dealing with mental health problems of adolescents. A visual approach to the issue of mental health, such as the use of comic books, has shown positive results. The evaluation of young people's answers has proven that this method was a way for them to get in touch with their own feelings and to talk about them without having to be afraid of what others might think. This may also be a good approach for young people in the future because it provides a safe environment, which is something different in the context/field of working with a specific and vulnerable 
population. By analyzing these dimensions, it is possible to conclude that the comic created through this project is easy to use because it is short and eventful, it allows the participants of the program to work together on their experiences which initiates developmental processes such as emotional literacy or the integration of other people's messages about themselves.

Key words: comic book art; prevention of emotional and behavioral problems; thematic analysis.

\section{Introduction}

Illustrative techniques are often applied in the field of activities aimed at socialemotional learning, with the purpose of preventing mental disorders and behavioral problems of children and young people, but also in work aimed at the treatment of the described problems (Shirley, 2001; Serjurie, 2012). Some psychotherapeutic approaches, such as the psychoanalytic or psychodynamic approach, use illustration as a way to gain insight into the unconscious (Bargmann, 2013). That is why illustrative techniques are often applied in the evaluation of changes in the psychotherapeutic process. Also, their role and application in the field of teaching skills necessary for maintaining mental health should not be ignored. Painting and drawing, and more recently photography and film, have been recognized as useful media in the creative expression of emotions of children and young people (Bride, Crowell, Baucom, Kaufman, O'Connor, Skidmore, \& Yaptangco, 2014). Of all the mentioned art techniques, this study will be oriented towards comic book art.

McCloud (1994 as cited in Tatalović, 2009) states that a comic consists of sequential connected images (frames) which, even though they prompt one's imagination, primarily form a textually based book. The application of comic book art in teaching and education is not a new concept. Numerous teachers used this concept 60 years ago, which is evident in the work of Sones from 1944 or Hutchinson from 1949 (Hutchinson, 1949; Sones, 1944). From 1935, when the first comic book was created, it was only a matter of years until its application in educational purposes started (Sones, 1944). Some facts about the application of comics which Sones (1944) had already pointed out were confirmed through years of research: it has the possibility to personalize and individualize the teaching process, it enables faster acquisition of knowledge passed on through the medium itself, it enables students to overcome the overload of school subject matter, it is suitable for "slow readers". In addition to all this, the children point out the most important advantages of comics such as their eventfulness, intrigue, illustration and the fact that they are short and interesting. Compared to other methods, using illustrations allows not only textual but also visual analysis which eases the process of teaching children and young people about complex concepts which young people must acquire, i.e. concepts they are facing for the first time (Sones, 1944). Williams (2008) emphasizes that comics are a very efficient means of teaching because reading or making comics enables young people to become more 
skillful in the critical understanding of the subject at hand. Also, comics can be used to examine and study personal experiences and encourage the empowerment of young people, empathy and connections between individuals.

Apart from the mentioned statements about the use of comic book art in educating young people, it is possible to find research in various fields of work such as: motivating children to acquire the skill of reading (Haugaard, 1973), teaching physics to the student population (Kakalios, 2001; Tatalović, 2009), or medical education and patient care (Green, 2010). Although the use of comic book art is not so present in the implementation of mental health programs, Branscum and Sharma (2013) point out that comic book art represents the basic education "tool", especially for children. Hosler and Boomer (2011) came to the same conclusion, recognizing that learning with the help of comic books is "easy" and that it increases the student's personal interest for the subject matter. They determined that comic books are an efficient educational tool which can motivate students to read and remember information, and they make the entire process fun. It is precisely the combination of words and images in comic books that gives them the potential to replace traditional textbooks (Tatalović, 2009). Hosler and Boomer (2011) systematically researched how much the use of comic books can influence less motivated students to learn and change their attitudes towards biology. More precisely, they wanted to see if they could motivate the students who are oriented towards social sciences to choose subjects from the field of natural sciences. They determined a statistically relevant improvement in students oriented towards social sciences, who have a lower level of knowledge in natural sciences, both concerning the knowledge and the attitude towards biology, as well as a bigger motivation to take up subjects from the field of natural sciences at the beginning of the school year. Gene (2003) stated the positive aspects of comic book art in education: a) motivation (due to human's fondness for images, comics can attract and keep the attention of readers); b) visual factor (images and texts intertwine and supplement each other, simultaneously "telling" a story); c) the presence of a "continuous" visual component (e.g. in a film the medium determines the tempo, whereas in comic books the reader determines the tempo due to the "constant visual element"); d) indirectness, because it is possible to use comic books to teach concepts which the reader, who might be hesitant, would not like to read about, research or experience, or if it is a difficult text or matter at hand; e) popularity (comics promote literacy and stimulate young people to become critical consumers of media messages); f) developing analytic and critical thinking skills.

The importance of using illustrative techniques, such as comic book art, in teaching, recognizing and verbalizing emotional states of children and young people, in the prevention of mental health problems and behavioral problems, can be corroborated by findings in various scientific disciplines. If the problem is observed from a neurobiological aspect (Ernst, 2009), the immaturity of certain brain structures is one of the reasons for failing to recognize other people's and a person's own feelings, 
which can then be manifested through reckless and inconsiderate behavior. From a psychological aspect, we can see how young people are focused on pleasant emotions and how the desire to arouse these emotions can force them to ignore the consequences of certain decisions and actions (Wang, Hipp, Butts, Jose, \& Lakon, 2015). The quest for excitement can be risky and dangerous if one loses a sense of boundaries and endangers one's own or somebody else's well-being. From a sociological aspect, the adolescent period is characterized by the need to socialize with peers more than ever in one's life (Claes, 1993). People will spend a large part of their life in the world of a group led and formed by peers. Therefore, it is important to get to know them, understand them and build a relationship which requires certain emotional competency. Susceptibility to external influences which are not always pleasant in today's modern society, often makes young people sensitive and insecure (Steinberg, 2007). Those are circumstances which they sometimes cannot influence, but can always choose how to deal with them if they develop good self-control (Allard \& Kesinger, 2013), where comic book art can definitely help.

The field of expressing feelings, moods and ideas is a neglected and rarely researched field (Jolley, 2010, as cited in Serjouie, 2012). Golomb and White's research (1992, as cited in Serjouie, 2012) points out some patterns which appear in children's drawings of emotional states. In a study including 176 primary school children, a majority of young people used the same colors to express happiness, sadness and fear. However, this was not just the case with colors but also with shape. Emotions were most often expressed through the position of lips and eyebrows, and by drawing tears. Young people making comics themselves has a special value. They become active creators and at the same time students and educators in the field of emotional states. If we take into consideration the unification which exists in children's art expressions, we can presume that young people will understand the morals of comics better if they are created by young people. However, we must point out that activities, which are from an educational aspect aimed toward teaching children and young people to verbally express visual features of certain pictures, are very rare. Levie (1978, as cited in Serjouie, 2012) emphasizes that interpreting pictures is also a skill which needs to be learnt and requires assistance. The interpretation of pictures is culturally conditioned. Charothers' and Gardner's research (1979, as cited in Serjouoie, 2012) shows that twelve-year-olds are able to recognize emotions in drawings. That is why the purpose of this study is aimed at assessing how young people see the purpose and how they understand the morals of the materials (comic books) which were created within the "Mostly Sunny" project.

Based on all of the above, the significance of comics is evident as an expressive technique, combining storytelling with imagery, that is artistic and narrative expression. In addition, comics can be used as a projective technique as they enable the grouping of experiences that are difficult to articulate into a whole, in a way that those experiences were not linked before (Porr, Mayan, Graffigna, Wall, Ramos, \& Vieira, 2011). The purpose of a projective technique is to work on unfiltered (sometimes 
even socially unacceptable) perceptions, feelings and desires. Linzey (1959, as cited in Porr et al., 2011) lists several types of projective techniques: associative techniques, filling-in techniques, constructive techniques, choice/order techniques and expressive techniques. The mentioned techniques enable us to work on expression which is not common in everyday work or conversations, and if we review the potentials of comics as a projective technique, they actually enable the incorporation of experiences into a story/novel in a new, untold way. Therefore, comics are an associative, constructive and expressive projective technique. As an associative technique, their aim is to present the first/immediate association. As a constructive technique, their aim is the creating of stories or images by individuals. If they are used as an expressive technique, then their aim is self-expression based on a certain stimulant.

As the focus of this study is directed towards analysis of the comic book as a technique in work with children and young people, we will begin with the assumption that this combination (associative, constructive and projective techniques) can help with the recognition and verbalization of psychological states. The current literature on the use of illustrative techniques with children and young people indicates potential benefits for children and young people, primarily in the prevention and treatment of emotional and behavioral problems. That is why the main goal of this study is directed towards verifying the applicability of comic book art as a method in a program whose aim is to recognize and determine personal and other people's emotions. Based on this goal, the following research questions were listed:

- How do young people understand the content and morals of comic books?

- Is the comic book useful in recognizing and determining emotions, from the perspective of children and adolescents?

- Do children and adolescents consider comic books useful for recognizing their own emotions?

\section{Creation of the Comic - The Description of the "Mostly Sunny" Project}

The Public Health Institute of Split-Dalmatia County - Mental Health Department, in partnership with The Education and Teacher Training Agency, initiated a project called "Mostly Sunny". The aim of this project was to stimulate emotional development, the recognition of personal and other people's emotions, and to stimulate the expression of personal feelings and needs in various, but socially acceptable ways, using verbalization rather than agitation. The expected outcomes of the project were a positive influence on school grades, a decrease in emotional problems and a decrease of addictive and other risky behaviors during future development of young people. The subject of mental health was approached in an interesting, familiar and appropriate way, using various media to express oneself (film, photography, writing, debate clubs, art and drama clubs, web-sites; the creation, design, preparation and printing of the outcome materials). The project consisted of activities which are appropriate for 
primary and high school students, the general population, but also for children and young people at risk, such as those in a specific environment like out-of-home care.

The project proposal's idea, procedural and content implementation took place in 2011 in educational institutions and social care institutions, while its realization is still ongoing. After the project's preparation and planning phase, its implementation began in academic year 2011/12, and is still ongoing with a continuous rise in the number of educational institutions and beneficiaries, children and adolescents involved in it. Keeping the project's goals in mind, over the past few years, various journalism, literary, art, drama and IT workshops were held, where students learnt about emotional and social skills, recognizing and controlling emotions, maintaining good relations with others and making responsible decisions, all with the purpose of preventing violent and suicidal behavior. There are numerous outcomes of this project, therefore we will list only a few: A Guide on Mental Health, a health calendar titled "An Emotional Carousel", a photography exhibition "When Thoughts Wander", the making and implementation of an educational game about emotions, etc. It is interesting that all outcome materials were produced by children and adolescents for children and adolescents with the mentorship of their teachers and school expert associates.

In this paper we will focus on the creation and implementation of comics as one of the outcome materials of the project in teaching children and adolescents about emotions. The first phase of the project consisted of the Comic book school in academic year 2013/2014, in partnership with the Info zona Split - a coalition of youth organizations, in whose premises the activities took place. Workshops held twice a week in a period of six months were led by academic painter Ivan Svaguša and psychologist Janina Pavić, while the participants were students from schools which were project partners. During this period, students learnt how to express their pleasant and unpleasant emotions in an adequate and socially acceptable manner. They also learnt how to express a certain emotion using various art techniques. As a product of these workshops, two comics were made: "Shadows" and "The Invisible Wall" which were created and drawn by the participants with the mentorship of workshop tutors. Therefore, the students came up with and made certain educational materials with the aim that they be used in educational institutions. There were 253 students who participated in the creation of these two comics.

Due to the fact that each type of art represents a certain kind of communication, this is also the case with comics which aim at stimulating personal engagement of the readers and especially the participants who went through a series of auto-reflective, self-analyzing exercises during which they thought about unpleasant feelings often difficult to talk about. In accordance with the project goal, a more specific goal was set for the evaluation of comics created within the project: to evaluate their applicability in work with children and young people, in a sense of helping them in the process of recognizing and determining personal and other people's feelings, which represents the second phase of the project implementation. Comics were used as a channel for expressing emotions and for talking about behavioral problems which complicate 
everyday functioning of children and young people, which will be presented further on in the paper.

\section{Methodology Subjects}

A survey was conducted amongst children and young people involved in the program in order to determine how much and in which way materials produced through creative workshops in the School of Comic Book Art help in recognizing and determining personal and other people's emotions. The targeted population were children and young people who participated in the "Mostly Sunny" program in 2014. Three groups of beneficiaries participated in the research: $5^{\text {th }}$ and $6^{\text {th }}$ grade students (231 students from primary schools in Makarska and Žrnovnica, $7^{\text {th }}$ and $8^{\text {th }}$ grade students (172 students from primary schools in Split, Stobreč, Žrnovnica and Kaštel Stari) as well as high school students (96 students from Medical High School Split), which gives a total of 499 participants. It should be pointed out that this included about 16\% of young people because 3000 students saw and used the materials.

\section{Data Collection and Description of Variables}

After participating in the "Mostly Sunny" project, participants filled out a Questionnaire about project experience, designed to evaluate the effectiveness of the project. The questionnaire consisted of four closed-ended questions (Do you like this way of presenting young people's problems/difficulties?; Do you think this comic book is useful?; Did you identify with the comic book content?; Do you think you could express your feelings in this way?) and three open-ended questions (Do you think this comic book is useful and why?; Why do you think you could express your feelings in this way?; What do you think is the message young people, authors of the comic book, want to convey with this comic?). Apart from the questionnaire, focus groups were organized with participants on the same subject. Surveys and group conversations were conducted by expert associates - psychologists in the listed schools. Children and youth participated in 35 focus groups throughout May, June and September 2014. There were about 10 to 15 participants in each group and the semi-structured interviews lasted for about 45 minutes. The participants' answers were noted during focus groups, providing material for content analysis. This combination of data collection methods was applied in order to, apart from gathering information from a large number of participants, establish indirect contact between the researchers and participants, which represents an important assumption of the qualitative research approach and can enrich the gathering of quantitative data (Milas, 2005).

\section{Data Processing Methods}

Answers to the closed-ended questions were analyzed at a descriptive level, and answers to open-ended questions were analyzed using qualitative analysis where the 
participants' answers represented empirical material, i.e. content which would be analyzed. Thematic framework analysis was chosen to process the data. Thematic framework analysis is a method of identification, analyzing and reporting certain patterns within the data and can include the interpretation of various aspects of research themes (Braun \& Clarke, 2006). Framework analysis enables systematizing and the initiation of analysis procedures according to a predetermined schedule. The chosen data analysis principal in thematic framework analysis originates from Lacey and Luff (2007). The method itself involves five key stages (Lacey \& Luff, 2007):

A. Familiarization: whole or partial transcription and reading of the data;

B. Identifying a thematic framework: this is the initial coding framework which is developed both from a priori issues and from emerging issues from the familiarization stage. This thematic framework should be developed and refined during subsequent stages;

C. Indexing: the process of applying the thematic framework to the data, using numerical or textual codes to identify specific pieces of data which correspond to differing themes (this is more commonly called coding in other qualitative analysis approaches);

D. Charting - creating thematic and case charts;

E. Mapping and Interpretation: this means searching for patterns, associations, concepts, and explanations in one's data.

The empirical structure was divided according to the schools the participants attended. All the answers were copied to Word documents, Times New Roman font, size 12 , spacing 1 . This is how 321 pages of text were produced, which were then used for analyzing and answering research questions.

Further on, using the methods of immersion and crystallization (Borkan, 1999), the theoretical framework was determined. Previously defined research questions were used. The next step of analysis was marking and sorting texts of each group according to the defined themes. A summary table was made, which contained three rows (for three previously defined themes) and four columns (theme, citations, notes and impressions, codes and patterns). The table was used for interpreting and recognizing patterns through which it is possible to describe the defined themes. As the analysis themes were primarily defined by questions young people were asked, the first step was reading each focus group after which notes and impressions were added to the answers. Codes and patterns which were used to describe certain subjects were defined based on the notes and impressions.

It is important to note that the first (getting acquainted with the matter) and second steps in analysis (determining the thematic framework) are based on an independent approach of three researchers. Each of them was introduced to the matter, gave suggestions about the themes and based on these suggestions, having in mind the goal that was supposed to be achieved, three themes were chosen (the usefulness of the materials, applicability of materials, understanding the moral of the comic). 
The indexing stage followed as well as the charting stage, which was done by two independent researchers. After those two stages, they worked together on mapping and interpreting. Finally, the report was written as well as the analysis of results.

\section{Evaluation Results of the "Mostly Sunny" Project Descriptive Results}

The evaluation results (Table 1) will be used for the purpose of analyzing the descriptive results.

Table 1

Presentation of "Mostly Sunny" evaluation results

\begin{tabular}{|c|c|c|c|c|c|c|c|c|}
\hline \multirow{2}{*}{ Question } & \multicolumn{2}{|c|}{ No } & \multicolumn{2}{|c|}{ Partially } & \multicolumn{2}{|c|}{ Mostly yes } & \multicolumn{2}{|c|}{ Completely } \\
\hline & $\mathrm{F}$ & $\%$ & $\mathrm{~F}$ & $\%$ & $\mathrm{~F}$ & $\%$ & $\mathrm{~F}$ & $\%$ \\
\hline $\begin{array}{l}\text { Do you like this way of presenting young } \\
\text { people's problems/difficulties? }\end{array}$ & 49 & 9.62 & 125 & 24.56 & 207 & 40.67 & 128 & 25.15 \\
\hline Do you think this comic is useful and why? & 32 & 6.56 & 70 & 14.34 & 219 & 44.88 & 167 & 34.22 \\
\hline Did you identify with the comic? & 195 & 39.24 & 176 & 35.41 & 86 & 17.30 & 40 & 8.05 \\
\hline $\begin{array}{l}\text { Do you think you could express your feelings } \\
\text { in this way? }\end{array}$ & 149 & 29.86 & 142 & 28.46 & 176 & 35.27 & 32 & 6.41 \\
\hline
\end{tabular}

Most participants answered the question Do you like this way of presenting young people's problems/difficulties? affirmatively, where slightly less than half (40.6\%) answered mostly yes, and a quarter answered completely. If we add a quarter of those who partially like this way of presenting young people's difficulties, we can conclude that over nine tenths of young people partially or completely have positive impressions.

Answers about the usefulness of comics were mostly positive. Namely, a majority of participants $(93.44 \%$ ) considered the comic to be at least partially useful, where $44.88 \%$ of participants answered mostly yes, $34.22 \%$ said completely and $14.34 \%$ said partially. Less than a tenth of participants (6.56\%) did not consider the comic to be useful.

If we consider the personal component of the material, meaning how young people perceive it to be personally useful, it is interesting that the majority of participants (39.24\%) did not identify with the comic although they considered it to be useful. Over a third of participants partially identified with it, while a quarter stated that they mostly or partially identified with it.

A majority of participants answered the question Do you think you could express your feelings in this way? with mostly yes (35.27\%). It is interesting that only $6.41 \%$ of the participants said they could completely express their feelings in this way. As the participants stated themselves, some of the reasons could be the complexity of experiencing certain emotions which makes it difficult to express them in this way (Some feelings cannot be expressed using neither words nor images). The percentage of those who could not or could only partially express their feelings in this way is almost 
equal and slightly less than $30 \%$ for each answer. This is probably due to the fact that some participants found other ways of expressing themselves (Sometimes I write songs. Songs about what is happening to me; I'm not really used to expressing my feelings like this; I could, but I'm not really sure how to say what I'm thinking about...).

\section{Interpretation of Qualitative Data}

A thematic framework analysis of texts produced using young people's answers to three open-ended questions shall follow. The results will be presented through three themes: the usefulness of the materials, the applicability of the materials and understanding the morals of the comics.

\section{Perception of the Material's Usefulness}

By analyzing the first theme (the usefulness of the material), eight dimensions were identified: stimulating people to think about their behavior, stimulating people to communicate and express emotions and thoughts, stimulating people to consider and solve young people's problems, teaching and passing on information to young people in a fun and approachable way, raising awareness about diversity amongst people, raising awareness on the importance of close relationships, artistic expression as a mean of solving psychological conflicts, and comics as a medium of project identification. Most of the young people's answers showed that they consider the comic to be useful, while a smaller number of participants considered the comic to be incomprehensive and useless (Not everybody has to understand what is drawn; I don't think it can help anyone).

The comic motivated some participants to think about their behavior and about the behavior of people around them (It has taught us to behave nicely; It can teach others what to do, and what not to do; It shows us certain situations and how we should behave in these situations; We can learn more about our own behavior). All this shows us that the comic book taught young people about the distinction between desirable and undesirable behavior, showed them how to behave in certain situations and pointed out the importance of good behavior. Some of them pointed out that it made openingup emotionally and accepting unpleasant feelings much easier, and finally encouraged them to seek help (People who have problems, fears, insecurities, when they read the comic, they might be able to open up to someone, accept their fears and help their friends). Individuals stated that they considered the comic to be useful because it motivated them to socialize and encouraged them to be cheerful, open and positive (Because young people can think about whether they are isolating themselves or are sociable and if they are trying to run away from themselves or have accepted themselves as they are; It is useful because it teaches us to be cheerful, bright and open; It stimulates young people to socialize more with their friends; Yes, because many of our peers isolate themselves between the walls of technology and don't let others in).

The second dimension which we were able to recognize during the analysis is Stimulating people to communicate and express emotions and thoughts. Some of the 
participants realized that the comic motivated them to communicate and to express emotions, which shows that it can be educational in the field of emotions (Because people need to learn to express their feelings. Because it is a bit easier to understand feelings. So that we can express our feelings. It is important to share feelings). The majority of participants described the comic as useful because it encourages opening-up emotionally (expressing emotions and thoughts), even though some showed suspicion towards creative expression as the main method of communicating with others (Many children have learnt how to knock down that invisible wall and show their feelings in this way; Because it helps us with our emotions in this stage in life; I think it is mostly useful because it shows us how to express our feelings, but I don't think it is the primary way to show your emotions; It partly helps us to awake the desire for talking and thinking about our problems, but in my opinion, sometimes we do not need various media to stimulate us to talk about our problems. Sometimes we can figure it out ourselves). Not only did young people recognize the importance of expressing emotions and feelings, but they were also stimulated to think about ways to solve problems (Because it helps young people to realize they are not alone and that everyone has their own problems they need to confront and not run away from). Based on their answers, it is evident that ways of confronting problems and their representation are appropriate for their age group. That is probably one of the reasons why young people identified with the problem being discussed, which made the process of opening-up emotionally (expressing emotions and thoughts) much easier (Yes, because problems and difficulties were depicted in an unusual way, familiar to young people). This way of expression got them thinking and showed them ways to solve problems (It shows us how we can solve problems. Because we have to understand that we need to confront our problems. Because it deals with problems that often occur amongst young people. It gets us thinking about our problems; Yes, because some people run away from their problems, but they still need to solve them).

The comic is useful because of its approach which enables learning in a fun and familiar way (Young people usually do not like to read long and boring texts, but seeing illustrations can motivate them to think.) The participants pointed out the educational component of the comic which indicates its efficiency (We can learn a lot from it; Because it is pragmatic and can be useful in our lives; It is informative and interesting and is also a form of informing young people; Because it is pragmatic and tells us more about feelings).

One of the goals of the comic was to emphasize the various approaches towards emotions, which was recognized by some young people. In the context of developing emotional competency, an important factor is empathy which enables the recognition and acceptance of different ways of expressing thoughts and emotions (We can see how different people express their feelings; Because everybody should express their feelings in their own way). It is evident that the comic served as a medium which raises awareness on the existence of diversity and promotes its embracement. Creative expression can serve as a stimulant for interaction with those who find it difficult to verbalize their 
emotions (Yes, because people who don't understand words can understand images and emotions in pictures).

Work on emotional competency is evident through raising awareness on the importance of close relationships, which the participants recognized themselves. Thinking about their behavior, they saw the consequences of bad behavior towards others, which additionally encouraged them in a sense of nurturing desirable behavior (Because it motivated us to think about our behavior towards others). It could be said that the comic taught them the importance of human relations, especially friendships (It shows the benefits of friendships; It shows us that friends are important).

Due to the fact that art is a form of communicating with the reader, it can be said that using other (not only verbal) channels has eased the expression of emotions of those who otherwise did not find this easy. Artistic expression served as a means for solving psychological conflicts, to reduce tension, which can be seen through the participants' answers (Yes, because people who don't understand words can understand images and feelings in pictures). This creative form of expressing thoughts and emotions is familiar to those who chose to express themselves this way and those who identified with what was expressed. The comic book served as a medium for transferring a part of their problems on to the main character who manages to successfully resolve them through the story (It eases people's problems just by reading it because they are also in the same situation; We recognized our own problems in this comic book; It helps because we are also in these situations; It can show young people that their problems are not unsolvable; Sometimes we are not aware of our problems or other people's problems so comic books like this should help people realize they are not alone; We all have our own problems or prejudices which we need to learn to solve). Young people described the comic to be useful because they believe that individuals in similar situations could be encouraged to take initiative in solving their own problems (I think this comic book is excellent because it talks about everyday problems which everyone can identify with; Because someone who reads the comic might be in the same situation and try to confront his/her problems).

\section{Perception of the Material's Applicability}

The second theme defined for thematic analysis is The perception of the material's applicability. Therefore, answers to the question Do you think you could express your feelings in this way? were analyzed. Through thematic analysis, six dimensions were produced: recognizing the importance of expressing emotions; recognizing the importance of dealing with problems; stimulating people to use visual methods of expression and communication; pointing out the need to share and help one another; therapeutic elements of comic books as an interactive medium; project identification through comics. These will be explained in detail further on in the paper.

Concerning the question on the perception of the material's applicability, a small number of participants expressed suspicion concerning their ability to express 
emotions through visual media. They think it would be easier to express themselves in a different way (I am not a fan of comics, I prefer books and like to express my feelings using words rather than images because I do not see the point in this; I cannot express myself in this way; It is difficult for me to express myself using drawings; I don't express my feelings in this way (you can't really see my feelings; I show my feelings to one person I trust). Some young people listed fear as a counter-effect (Because we can make other people sad) and a lack of desire to confide and communicate (Because I mostly do not want other people to know how I feel; I would rather solve problems myself and keep them to myself; I do not feel comfortable when I express my feelings in any way...), even though they are prepared to try if they think it will help someone else (I don't like talking about my feelings, except with my best friend. If I knew it would help someone, I would probably have the courage to make a comic book).

Most participants recognized the importance of expressing emotions and determined that the comic book made it much easier and enabled them to do so in an interesting way (Because you can express your feelings more easily and calmly; Because this is a nice way to express feelings; Because it is easy to express your feelings using a pen and paper; Because it is the best and easiest way to express feelings). Not only does it teach them the importance of expressing emotions, but it also stimulates them to do it in a socially acceptable way (Because I am not afraid to express my feelings and I do not run away from them; Yes, because when I am happy I share my happiness with others). Drawings as a means of expression are seen in all cultures, so universal emotions can be expressed through them (Because anyone who has feelings can understand them even in a comic book without text and can express them because everyone understands them).

The applicability of the materials was also determined through recognizing the importance of confronting problems, which one participant pointed out by expressing the desire to confront his problems using this type of media (Because I also have some problems and would like to express them through a comic book). In this context, we can also recognize the importance of comics as a means for articulating internal conditions and the possibility to use them in the process of developing emotional competency. Young participants have accepted a creative (especially visual) method of expression and communication, and pointed out some of its advantages (When I am sad and when I have problems, maybe I could try; Because it is fun to show this through a comic instead of a book which is boring; It is easier like that, when I arrange everything on paper, then I see what is bothering me and it is not so bad), but also some of its disadvantages which are related to the fact that some emotions cannot be expressed in this way (In some situations I could. Happiness, sadness and anger I can express, but some feelings are too complicated to express in this way). The significance of the comic is also evident through the need to share thoughts and emotions and to help each other, which the participants expressed after reading the comic. Some of the young people pointed out that the comic inspired them to express emotions and to communicate about their difficulties and seek help, and truly desire that help (Because if we express them, they 
won't stay inside us; Because others could help me; Because I will be able to show others my feelings; Because we feel better when we tell someone how we feel; Because I would like to share some things with others; Yes, because I would like to help my peers and adults to break down their walls; Because I always help and want to be in the company of isolated people, I want to break down that "wall").

The therapeutic elements of the comic book as an interactive medium can be seen in the participants' answers which emphasized the calming effect it had on them (Pictures and colors help, they show deep emotions and help in calming down; It is much easier to express yourself through art. Many may not recognize your feelings, but you will feel better). Also, some participants find it easier to cope with unpleasant emotions in this way such as sadness, anger and anxiety (Because when I am sad, I go to my room and start drawing; Because it is not bad and we get everything out; Because when I am angry and in a bad mood, I take a piece of paper and color).

Some participants identified with the main characters of the comic books, which made it easier for them to cope with certain emotions depicted in the comics. This represents one of the reasons why young people accepted the comics and considered them to be appropriate (Because I experienced all that; Yes, because I feel the same in those situations; Because I also feel like I don't fit in sometimes).

\section{Understanding the Morals of the Comics}

The third theme was related to understanding the morals of the comics, and through analysis six dimensions were recognized (confronting your own feelings; emphasizing the importance of relationships; emphasizing the importance of communication; promoting the acceptance of differences amongst people; promoting development and a positive attitude towards life; encouraging people to accept help). Through their answers to the question "What message did the authors of the comic want to send?", young people mostly showed understanding which is compatible with the idea the comic book authors had when creating it.

Some of them came to the conclusion that the comic book authors were saying that you need to confront your problems and feelings, and not run away from them, where the importance of determination and adaptation was emphasized, as well as a kind of independence in dealing with difficulties (They wanted to teach us to be determined and never give up; That you need to deal with your problems and worries, not hide between four walls, but socialize with friends; If nothing changes, we need to change; We should not give up on the world and our goals. Sometimes we need to experience failure to become stronger and more determined in our goals). Young participants recognized one message as the need to confront ourselves, our own emotions and fears (They wanted to tell us not to run from ourselves; Being afraid of failure is not success, failure is when we give up trying to succeed).

The participants also recognized the message concerning the importance of bonding and building close relationships with people. Through their answers they showed that 
they recognized the importance of an appropriate attitude towards emotions and problems, as well as the importance of investing in close relationships (You can get angry sometimes, but don't take it out on your friends; They wanted to tell you that you need to make an effort to take the first step forward, to respect your friends and to try and be nice if you have been rude). They also pointed out the role of emotional support as a factor in building and maintaining close relationships (You need to make an effort for friendship because it is one of the most valuable things. When someone wants to help you, it's very nice).

Some of the participants mentioned communication as one of the methods of sharing emotions and problems. They emphasized the importance of expressing and sharing emotions and thoughts, and they recognized that the authors pointed out various ways to approach emotions (Young authors wanted to say that you can set your feelings free; They wanted us to know that our fears, our inability to open up, often inhibit us. If we confided in someone and accepted help, we would be able to get past those fears). They also recognized the message to accept diversity amongst people, especially when it comes to different ways of expressing emotions (They wanted to say that everyone expresses feelings in their own way; It is not alright to mock anyone; Respect others).

Young participants also think that the comic book promotes the development of a positive attitude towards life, which includes accepting the world as it really is - with all the difficulties that come with it. They see that the role of perceiving these problems is key (When we accept our problems, the day will be sunnier). We can say that the comic book is stimulating in a sense of motivating people to find solutions and dealing with problems (I think they wanted to show us that we can solve anything; They wanted us to inherit the positive attitude towards the world, stimulate us to find solutions, to talk about our emotions and confront our fears). They realized that only by accepting ourselves we can experience the true beauty of life in all its glory (We should focus on a better tomorrow and accept ourselves the way we are, with all our virtues and flaws; We must relax, knock down the walls and simply loosen up and then we will be better for ourselves and our surroundings).

Through their answers, young people pointed out the importance of accepting help and helping others in their time of need (We should not be rough towards others and should offer our help; We should always accept help because it is not easy to deal with problems alone; Despite our ability to solve problems, we could always use some help; When we accept someone's help, we will know when and how to help ourselves and others. The perception is different, the other side of the world is prettier, the shadows are acceptable, help others, simple). They recognized the importance of tolerance, emotional support and accepting help as key factors in the process of accepting ourselves.

\section{Discussion of the Results}

The quantitative and qualitative results show coherence in the perception of the analyzed materials (the comic book) and this is not surprising. A great success is the 
fact that the qualitative results explain the basic quantitative results, in other words, they enable explanations and a deeper insight. If we look at the general impressions of young people concerning the materials, we can see that they perceive the presented materials in a positive light, whether partly or completely. This is related to the approval of this type of representing problems and the usefulness of the produced materials (comic book). Further on, the quantitative indicators show that the perception of the personal applicability of the materials is not coherent with this general positive impression. A small percentage of young people said they identified with the comic and that this could be "their" way of working on recognizing and expressing emotions. The qualitative data enables us to see the greater importance of these general indicators. Through thematic framework analysis, the identified dimensions can be used in order to conclude why the general impression is positive and how young people recognize the applicability of the materials (Table 2). The identified dimensions were presented at a level of general impressions and at a personal level in order to identify what personal gain young people recognized from working on the comic.

Table 2

Dimensions generated at a level of thematic analysis

\begin{tabular}{|c|c|c|c|}
\hline \multirow{2}{*}{$\begin{array}{l}\text { Perception } \\
\text { level }\end{array}$} & \multicolumn{3}{|c|}{ Themes } \\
\hline & $\begin{array}{l}\text { Perception of } \\
\text { material's usefulness }\end{array}$ & $\begin{array}{l}\text { Perception of material's } \\
\text { applicability }\end{array}$ & $\begin{array}{l}\text { Understanding the morals of } \\
\text { the comic books }\end{array}$ \\
\hline 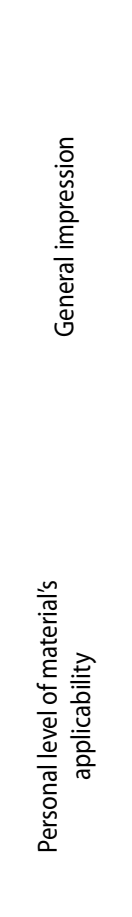 & $\begin{array}{l}\text { Stimulating people to } \\
\text { communicate and express } \\
\text { emotions and thoughts. } \\
\text { Stimulating people to think, and } \\
\text { ways of solving young people's } \\
\text { problems. } \\
\text { Educating and passing on } \\
\text { information in a way which } \\
\text { is fun and familiar to young } \\
\text { people. } \\
\text { Artistic expression as a means of } \\
\text { solving psychological conflicts. } \\
\text { Comic book art as a project } \\
\text { identification medium. }\end{array}$ & $\begin{array}{l}\text { Recognizing the } \\
\text { importance of } \\
\text { expressing emotions. } \\
\text { Recognizing the } \\
\text { importance of } \\
\text { confronting problems. } \\
\text { Emphasizing the } \\
\text { need for sharing } \\
\text { and mutual } \\
\text { assistance. } \\
\text { Project identification } \\
\text { through comic books. }\end{array}$ & $\begin{array}{l}\text { Confronting your own } \\
\text { emotions. } \\
\text { Pointing out the } \\
\text { importance of } \\
\text { relationships. } \\
\text { Pointing out the } \\
\text { importance of } \\
\text { communication. } \\
\text { Stimulating people to } \\
\text { accept diversity amongst } \\
\text { each other. } \\
\text { Stimulating the } \\
\text { development of a } \\
\text { positive attitude } \\
\text { towards life. } \\
\text { Encouraging people } \\
\text { to accept help. }\end{array}$ \\
\hline
\end{tabular}


If we look at the determined dimensions on the level of thematic analysis, it is obvious that young people describe benefits and recognize the usefulness of the materials at two levels. At a general level, young people describe gaining something from working on these materials. We can assume that young people recognized the processes which took place during work on the materials, and they talk about the comic's potentials at a general level of its applicability in work with young people. They recognize that the comic could generally be useful in educating people on the emotional aspect, that it could stimulate socialization, talking and opening up, that it is a fun media and can be a means for solving problems. Apart from this general impression, young people describe personal gain from working on these materials (comics). They emphasize that the comic helped them gain insight into the diversity of perceiving and expressing emotions, into the importance of relationships and friendships in solving problems and the fact that they are not the only ones with problems and are not alone. Even though they think the comic books can stimulate people to open up emotionally, some young people still express hesitation towards creative expression as a main method of communication with others. When considering the young people's answers on how the comic can serve as a medium for opening up, talking and learning about emotions, other aspects necessary for working on emotions must not be neglected (a safe environment, trust amongst group members). Considering that it all took place in a classroom where the educational component is highly present, the two-dimensionality of answers is not surprising. However, it is also important to note the possibilities young people recognized if the environment was different and safer, where there was more trust, and which is oriented towards solving emotional problems.

Concerning the Perception of the material's usefulness, young people primarily expressed their opinion on whether artistic expression and illustration is their way of expressing emotions. If they considered artistic expression and projective techniques to be their method of expression, they pointed out the advantages of using the comic book, especially in an emotional sphere, in cases when they wanted to express unpleasant emotions such as sadness, anger and anxiety. They see that this way of expressing emotions, which is easier with the help of the comic book, is socially acceptable and enables them to start confronting problems, to communicate about difficulties and to seek help. Furthermore, young people also said that, through working on the comic book, they recognized their own wish to help others. Their perception of the material's applicability was also influenced by the process of identifying with the main characters. However, if young people feel that comic book art is not the adequate media for expressing emotions, then they usually recognize its general usefulness in working with young people, but not for them personally. These answers warn us about the possible challenges of using this type of media: some think it would be difficult to express emotions using a visual media, and that there are possible negative influences of this work method if there is no trust amongst group 
members. These answers also show us how important it is to create a safe environment and have alternatives in certain situations when working on recognizing emotions. On the other hand, this medium enables us to teach young people how to help others.

The third problem question was related to young people's perception of the comics' moral. The way young people perceived the moral of the comic books is coherent with the personal and general gain recognized through the first two analysis themes, which is not surprising. That is why it is possible to connect the generated dimensions in the third theme with the goal of the project and purpose of the comics. Due to the fact that the goal of this project was to stimulate emotional development, recognize personal and other people's emotions, and expressing emotions in a socially acceptable way, the same goals can be seen in the understanding of the comics' morals. When it comes to emotional development, young people recognized that the purpose of the comics was to raise awareness on confronting problems and feelings, and not running away from them. It is important to see that the comic can be a means of communicating about emotions and problems which someone has and wants to solve. The next goal was related to recognizing one's own emotions and the emotions of others. The fact that young people recognized the comic's messages concerning their personal development and the development of relationships is the proof of achieving this goal. At a personal level, we can distinguish a message that promotes a positive attitude towards life with all the various difficulties it comes with. At a level of building relationships, young people felt that the comic was telling them how important it is to connect with people and establish close relationships, accept and offer help to others and accept differences in ways of expressing emotional states. With all these gains, analysis shows that comic book art is an appropriate technique for the socio-emotional education of children and young people.

By summing up what young people gained through participating in the comic book activities, the potentials of this technique are obvious. It is crucial to point out that the technique was generally well accepted by young people. They consider the comic to be an appropriate and interesting work method. In the context of dimensions determined through various thematic analyses, it is clear that young people recognize comic book art to be a technique which enables the recognition of personal emotions, the verbalization of unpleasant emotions, accepting help from others and offering help, building close relationships and accepting differences amongst people in their ways of expressing emotions. Young people who did not perceive the comic book in such a positive way are the crucial source of information for creating future activities using this medium. Namely, even though a number of young people stated that artistic expression is not their preferred method of dealing with emotions, they did not ignore the fact that a precondition for this type of work is creating a safe and trusting environment. We should keep this in mind when planning further activities using this technique because, apart from the implementation of these or similar illustrative techniques, it is necessary to prepare the group for working on the comics by creating 
a pleasant atmosphere, establishing trust amongst group members where they will feel safe to express emotions, and teach them how to provide help and support in difficult moments and show understanding. This can be accomplished by teaching young people communication skills such as empathic listening, assertive expression of personal needs and accepting differences. This kind of safe group environment would enable the revelation and exploration of your own uniqueness, which represents a very important development task in the adolescence period (McFerran-Skewes, 2004). In order for these processes to contribute to the positive development of mental health, the harmony between perceptions and feedback of people concerning themselves is important. As this process of harmonizing other people's messages with their own image represents a risky process, especially with young people who do not prefer verbal expression, illustrative techniques have a great importance in this process of self-revelation and receiving feedback information from their surroundings. Apart from that, comic books are materials which children read with equal effectiveness (Sones, 1944) making it an excellent medium for children and young people who show certain risks in the field of education such as bad grades, specific difficulties in reading or writing and a lack of motivation to acquire certain knowledge.

The value of this project result is related to the ability of young people to understand the messages conveyed by young people through the comics. Due to the fact that the way all these young authors represent emotional states is quite similar and age appropriate, we can assume that young people are the best authors for this type of texts and imagery. Reading the comic can potentially enable the projection from the comic book characters, which is a precondition for authentic expression in a group context.

\section{Conclusion}

In a safe environment with well-structured group work, the product of this project (the comic book) can have two advantages: it is easy to use because it is short and eventful, and it also enables the participants of the group program to work together on what they perceived, which initiates development processes such as emotional literacy or integrating messages about themselves.

Children and young people need a safe educational environment where they can express emotions and learn about them. The school and other staff in institutions where project beneficiaries live or reside can stimulate and support this aspect of personal growth through interactive activities in continuous work. In this research, young people especially emphasized the importance of a safe environment for working on expressive techniques such as comics.

The combination of art (images) and narration (text) makes it easier for children and young people to talk about feelings and problems they are faced with. Some participants were prompted to think about emotional and some about behavioral components. Apart from that, the participants recognized the usefulness of the comic not only for themselves but for their peers as well. They can send various messages 
using the comic (raising awareness on differences between people, emphasizing the importance of close relationships), and this method of expression can make it easier for young people to solve some of their psychological conflicts and transfer their personal problems on to the main characters who successfully solve them, promoting self-aid during the identification process.

Despite the fact that comics are a simple and fondly accepted work technique amongst young people, they are rarely made and used with young people. Thus, these cognitions gain importance, though we still need to be aware of their methodological constraints. In order to evaluate the direct gains of working on the comics as educational materials, it is important to plan further implementation of the project and the assessment of achievements. In accordance with this, further plan is to evaluate potential changes in the young participants while working on the materials, with the aim of evaluating the applicability and usefulness of the materials. This is how we can overcome the limitations of the results obtained so far, which give us a general impression of a larger number of young people, while by creating detailed insights into the changes and benefits within the targeted population we will get a new dimension of information concerning this technique.

Looking at all of the above, it is obvious that the "Mostly Sunny" project is useful and that it is crucial that its implementation continues while including a larger number of beneficiaries from various schools and surroundings. It is important to raise awareness and promote the importance of mental health development of children and young people with the help of the local community and the media.

\section{References}

Allard, E. S., \& Kesinger, E. A. (2014). Age-related difference in functional connectivity during cognitive emotion. The Journals of Geronthology, 69(6), 852-860. 18. https://doi. org/10.1093/geronb/gbu108

Bargmann, J. (2013). The pictorial expression of aggression in the drawings between the ages of 14 and 16. Psychiatria Hungarica, 28(1), 58-69. https://doi.org/10.1016/S1526$\underline{4114(15) 30392-9}$

Borkan, J. (1999). Immersion/Crystallization In B. F. Caterbee, \& W. L. Miller (Eds.), Doing Qualitative Research (pp. 179-194). Thousand Oaks, CA: Sage Publications.

Braun, V., \& Clarke, V. (2006). Using thematic analysis in psychology. Qualitative Research in Psychology, 3 (2), 77 -101. https://doi.org/10.1191/1478088706qp063oa

Branscum, P., \& Sharma, M. (2009). Comic books: an untapped medium for health promotion. American Journal of Health Studies, 24, 430-439.

Bride, D. L., Crowell, S. E., Baucom, B. R., Kaufman, E. A., O’Connor, C. G., Skidmore, C. R., \& Yaptangco, M. (2014). Testing the effectiveness of 3D film for laboratory-based studies of emotion. PloS one, 9(8), e105554. https://doi.org/10.1371/journal.pone.0105554

Claes, M. (1993). Characteristics and functions of friendship in adolescence. Psychiatric Enfant, 36(1), 289-308. 
Ernst, M. K. K. (2009). Cerebral maturation in adolescence: behavioral vulnerability. Encephale, 35(6), 182-189. https://doi.org/10.1016/S0013-7006(09)73469-4

Gene, Y. (2003). Comics in Education. Retrieved from http://humblecomics.com/comicsedu/ index.html

Green, M. J., \& Mayers, K. R. (2010). Graphic medicine use of comics in medical education and patient care. British Medical Journal, 340, 574-577. https://doi.org/10.1136/bmj.c863

Haugaard, K. (1973). Comic books: conduits to culture. Reading Teacher, 27, 54-55.

Hosler, J., \& Boomer, K. B. (2011). Are comic books an effective way to engage nonmajors in learning and appreciating science? CBE Life Sciences Education, 10(3), 309-317. https:// doi.org/10.1187/cbe.10-07-0090

Hutchinson, K. (1949). An experiment in the use of comics as instructional material. Journal of Educational Sociology, 23, 236-245. https://doi.org/10.2307/2264559

Kakalios, J. (2002). Adding Pow to your physics class with comic-book lessons. Curriculum Review, 14-15.

Lacey, A., \& Luff, D. (2009). Qualitative data analysis. The NIHR RDS for the East Midlands: Yorkshire \& the Humber.

McFerran-Skewes, K. (2004). Using Songs with Groups of Teenagers: How Does It Work? Social Work with Groups, 27(2/3), 143-157. https://doi.org/10.1300/J009v27n02 10

Milas, G. (2005). Istraživačke metode u psihologiji i drugim društvenim znanostima. Jastrebarsko: Naklada Slap.

Porr, C., Mayan, M., Graffigna, G., Wall, S., \& Ramos Vieira, E. (2011). The Evocative Power of Projective Techniques for the Elicitation of Meaning. International Journal of Projective Methods, 10(1), 30 -41. https://doi.org/10.1177/160940691101000103

Serjouie, A. (2012). Children's understanding of pictures and expression of emotion in their drawings. (Doctoral Dissertation). Efurt: Art Education Faculty, University of Erfurt, Germany.

Shirley, R. (2001). Art therapy with adolescents. Western Journal of Medicine, 175, 54-57. https://doi.org/10.1136/ewjm.175.1.54

Sones, W. W. D. (1994). The comics and instructional method. Journal of Educational Sociology, 18, 232-240. https://doi.org/10.2307/2262696

Steinberg, L. (2007). Risk-taking in adolescence: New perspectives from brain and behavioral science. Current Directions in Psychological Science, 16(2), 55-59. https://doi.org/10.1111/ j.1467-8721.2007.00475.x

Tatalović, M. T. (2009). Science comics as tools for science education and communication: a brief exploratory study. Journal of Science Communication, 8(4), 1-17. https://doi. org/10.22323/2.08040202

Wang, C., Hipp, J. R., Butts, C. T., Jose, R., \& Lakon, C. M. (2015). Alcohol use among adolescent youth: the role of friendship networks and family factors in multiple school studies. PloS one, 10(3), e0119965. https://doi.org/10.1371/journal.pone.0119965

Williams, R. M. C. (2008). Image, Text and Story: Comics and Graphic Novels in Classroom. Art Education, 61(6), 13 - 19. https://doi.org/10.1080/00043125.2008.11652072 


\section{Zvonimir Parać}

Third Grammar School

Kamila Firingera 14, 31000 Osijek, Croatia

zvonimirparac@gmail.com

\section{Katarina Kružičević}

Center for Children, Young People and Family Duga

Zvonimirova 75, 21, 21210 Solin, Croatia

katarina.kruzicevic1@gmail.com

\section{Gabrijela Ratkajec Gašević}

University of Zagreb, Faculty of Education and

Rehabilitation Sciences,

Campus Borongaj, Borongajska 83f, 10000, Zagreb, Croatia

gabrijela.ratkajec.gasevic@erf.hr

\section{Mirela Grbić}

Service of Mental Health, Public Health Institute,

Split-Dalmatia County

Vukovarska 46, 21000 Split, Croatia

mirela.grbic@gmail.com

\section{Željko Ključević}

Service of Mental Health, Public Health Institute,

Split-Dalmatia County

Vukovarska 46, 21000 Split, Croatia

zeljko.kljucevic@gmail.com 


\section{Appendix}

\section{Protocol for thematic framework analysis}

\begin{tabular}{|c|c|c|c|}
\hline Themes & $\begin{array}{c}\text { Primary and secondary } \\
\text { school } \\
\text { students (original } \\
\text { answers) }\end{array}$ & $\begin{array}{l}\text { Notes and } \\
\text { impressions }\end{array}$ & Dimensions \\
\hline $\begin{array}{l}\text { Perception } \\
\text { of material's } \\
\text { usefulness }\end{array}$ & $\begin{array}{l}\text { It stimulates young } \\
\text { people to socialize } \\
\text { more with friends }\end{array}$ & $\begin{array}{l}\text { It stimulates } \\
\text { socialization }\end{array}$ & $\begin{array}{l}\text { Stimulating people } \\
\text { to think about their } \\
\text { behavior }\end{array}$ \\
\hline $\begin{array}{l}\text { Perception } \\
\text { of material's } \\
\text { usefulness }\end{array}$ & $\begin{array}{l}\text { We recognize our own } \\
\text { problems in the } \\
\text { comic book }\end{array}$ & $\begin{array}{l}\text { It allows you to } \\
\text { identify with the } \\
\text { problems }\end{array}$ & $\begin{array}{l}\text { Comic book as a } \\
\text { medium of project } \\
\text { identification }\end{array}$ \\
\hline $\begin{array}{l}\text { Perception of } \\
\text { applicability } \\
\text { (Does it enable } \\
\text { the expression of } \\
\text { emotions? }\end{array}$ & $\begin{array}{l}\text { Because when I am } \\
\text { sad, I go to my room } \\
\text { and start drawing }\end{array}$ & $\begin{array}{l}\text { It makes it easier to } \\
\text { express unpleasant } \\
\text { feelings }\end{array}$ & $\begin{array}{l}\text { Therapeutic elements } \\
\text { of the comic book as } \\
\text { an interactive medium }\end{array}$ \\
\hline $\begin{array}{l}\text { Perception of } \\
\text { applicability } \\
\text { (Does it enable } \\
\text { the expression of } \\
\text { emotions?) }\end{array}$ & $\begin{array}{l}\text { Because anyone } \\
\text { who has feelings can } \\
\text { recognize them in } \\
\text { the comic book, even } \\
\text { without words, and } \\
\text { can express them } \\
\text { because everyone } \\
\text { understands feelings }\end{array}$ & $\begin{array}{l}\text { Drawings as a means } \\
\text { of depicting the } \\
\text { universal }\end{array}$ & $\begin{array}{l}\text { Recognizing the } \\
\text { importance of } \\
\text { expressing emotions }\end{array}$ \\
\hline $\begin{array}{l}\text { Understanding the } \\
\text { moral of the comic } \\
\text { books }\end{array}$ & Respect others & $\begin{array}{l}\text { It teaches you to } \\
\text { respect others }\end{array}$ & $\begin{array}{l}\text { Promoting the } \\
\text { acceptance of diversity } \\
\text { amongst people }\end{array}$ \\
\hline $\begin{array}{l}\text { Understanding the } \\
\text { moral of the comic } \\
\text { books }\end{array}$ & $\begin{array}{l}\text { Life is not always } \\
\text { perfect, but we can } \\
\text { cope with that }\end{array}$ & $\begin{array}{l}\text { We need to deal with } \\
\text { everything we are } \\
\text { confronted with }\end{array}$ & $\begin{array}{l}\text { Promoting the } \\
\text { development of a } \\
\text { positive attitude } \\
\text { towards life }\end{array}$ \\
\hline
\end{tabular}




\section{Primjena ilustrativnih tehnika u poučavanju djece i mladih o emocijama}

\section{Sažetak}

Umjetnička tehnika stripa rijetko je analizirana kao ekspresivna tehnika unutar polja mentalnog zdravlja i prevencije problema u ponašanju djece i mladih. Zbog toga je cilj ove studije usmjeren prema analiziranju potencijala umjetnosti stripa kao ekspresivne tehnike. Koristili su se rezultati evaluacije projekta Većinom sunčano i primijenjene kvalitativne istraživačke metode. Podatci su dobiveni putem evaluacijskih upitnika; grupni razgovori analizirani su na deskriptivnoj razini i putem tematskog okvira analize. Kvantitativni i kvalitativni indikatori pokazuju koherentnost u dojmovima analiziranih materijala. Analizom tematskog okvira, $s$ tri unaprijed definirane teme (korisnost materijala, razumijevanje primjenjivosti materijala i razumijevanje pouka stripa), utvrdena je 21 dimenzija. Za adolescente su svojstvene teškoće pri verbaliziranju misli i emocija. U bavljenju problemima mentalnog zdravlja adolescenata koristili su se razni pristupi. Vizualni pristup problemu mentalnog zdravlja, poput upotrebe stripova, pokazao je pozitivne rezultate. Evaluacija odgovora mladih ljudi potvrdila je ovu metodu kao način na koji se mogu povezati s vlastitim osjećajima i razgovarati o njima bez straha od tuđeg mišljenja. To bi također mogao biti dobar pristup za mlade u budućnosti jer daje sigurnu okolinu, što je nešto drugačije u kontekstu/polju rada sa specifičnom i ranjivom populacijom. Analizirajući te dimenzije, moguće je zaključiti da je strip stvoren u ovom projektu lak za upotrebu jer je kratak i sadržajan; dopušta sudionicima programa zajednički rad na izražavanju njihovih iskustava koja potiču razvojne procese poput emocionalne pismenosti ili integracije poruka drugih ljudi o njima samima.

Ključne riječi: prevencija emocionalnih problema i problema u ponašanju; tematska analiza; umjetnost stripa.

\section{Uvod}

Ilustrativna tehnika često se primjenjuje u polju aktivnosti usmjerenih na socijalnoemotivno učenje sa svrhom prevencije mentalnih poremećaja i problema u ponašanju djece i mladih, ali također i u radu usmjerenom tretmanu opisanih problema (Serjurie, 2012; Shirley, 2001). Neki psihoterapeutski pristupi, poput psihoanalitičkog ili 
psihodinamičkog pristupa, koriste se ilustracijom kao načinom dobivanja uvida u nesvjesno (Bargmann, 2013). Zato se ilustrativne tehnike često primjenjuju u evaluaciji promjena u psihoterapeutskom procesu. Ne smijemo zanemariti ni njihovu ulogu $\mathrm{i}$ primjenu u polju podučavanja vještina potrebnih za održavanje mentalnog zdravlja. Slikanje i crtanje, u novije vrijeme fotografija i film, prepoznati su kao korisni mediji u kreativnom izražavanju emocija djece i mladih (Bride i sur., 2014). Od svih spomenutih umjetničkih tehnika ova studija orijentirat će se prema umjetnosti stripa.

McCloud (1994, citirano u Tatalović, 2009) navodi da se strip sastoji od sekvencijalno nanizanih slika (okvira) koje, čak iako potiču vašu maštu, primarno formiraju knjigu zasnovanu na tekstu. Primjena umjetnosti stripa u podučavanju i obrazovanju nije novi koncept. Brojni su se učitelji koristili tim konceptom prije 60 godina, što je vidljivo u radu Sonesa iz 1944. godine ili Hutchinsona iz 1949. godine (Hutchinson, 1949; Sones, 1944). Od 1935. godine, kada je stvoren prvi strip, samo je bilo pitanje vremena kada će se on početi koristiti u obrazovne svrhe (Sones, 1944). Neke činjenice o primjeni stripova koje je Sones (1944) već istaknuo, potvrđene su tijekom godina istraživanja: ima mogućnost personalizacije i individualizacije procesa podučavanja, omogućava brže stjecanje znanja koje se prenosi samim medijem, omogućava učenicima da nadvladaju teret školske predmetne građe, primjeren je za „spore čitače”. Dodatno, djeca sama ističu najvažnije prednosti stripova poput njihove narativnosti, intrige, ilustracija i činjenice da su kratki i zanimljivi. Kad se usporedi s ostalim metodama, upotreba ilustracija dopušta ne samo tekstualnu već i vizualnu analizu, što olakšava proces podučavanja djece i mladih o složenim konceptima koje moraju usvojiti, tj. konceptima s kojima se suočavaju prvi put (Sones, 1944). Williams (2008) naglašava kako su stripovi vrlo učinkovito sredstvo podučavanja jer čitanje ili stvaranje stripova omogućava mladima da postanu vještiji u kritičkom razumijevanju predmetne građe. Također, stripovi se mogu koristiti za ispitivanje i proučavanje osobnih iskustava, poticanje osnaživanja mladih, razvoj empatije i veza među pojedincima.

Osim spomenutih tvrdnji o primjeni umjetnosti stripa u obrazovanju mladih, moguće je naći istraživanja u raznim poljima rada: motivacija djece za stjecanje vještine čitanja (Haugaard, 1973), podučavanje učeničke populacije fizici (Kakalios, 2001; Tatalović, 2009), medicinsko obrazovanje i briga o pacijentu (Green, 2010). Iako upotreba umjetnosti stripa nije toliko prisutna u primjeni programa mentalnog zdravlja, Branscum i Sharma (2013) ističu kako strip predstavlja osnovni obrazovni „alat”, posebno za djecu. Hosler i Boomer (2011) došli su do istog zaključka, navodeći kako je učenje uz pomoć stripova „lako" i povećava učenički osobni interes za predmetnu građu. Oni su utvrdili da su stripovi učinkovito pedagoško sredstvo koje motivira učenika na čitanje, zapamćivanje informacija, a uz to cijeli proces čine zabavnim. Upravo kombinacija riječi i slika u stripovima daje im potencijal nadilaženja tradicionalnih udžbenika (Tatalović, 2009). Hosler i Boomer (2011) sustavno su istraživali utjecaj upotreba stripova na manje motivirane učenike, $u$ smislu učenja i promjene njihovih stavova prema biologiji. Preciznije, željeli su vidjeti mogu li potaknuti učenike koji su 
orijentirani prema društvenim znanostima da odaberu predmete iz polja prirodnih znanosti. Utvrdili su statistički značajan napredak učenika orijentiranih prema društvenim znanostima, koji imaju manju razinu znanja iz prirodnih znanosti, oboje u vezi sa znanjem i stavovima prema biologiji, kao i većom motivacijom za odabiranjem predmeta iz polja prirodnih znanosti na početku školske godine.

Gene (2003) navodi pozitivne aspekte umjetnosti stripa u obrazovanju: a) motivacija (zbog ljudske sklonosti slikama stripovi mogu privući i zadržati pažnju čitatelja); b) vizualni čimbenik (slike i tekst se isprepleću i međusobno nadopunjavaju, simultano pričajući priču); c) prisutnost „kontinuirane” vizualne komponente (npr. u filmu medij određuje tempo, a u stripovima to čini čitatelj zbog „konstantnog vizualnog elementa”); d) neizravnost (jer je moguće koristiti se stripovima za poučavanje koncepata o kojima čitatelj, koji može oklijevati, ne bi inače htio čitati, istraživati ili iskusiti; ili ako je riječ o teškom tekstu ili predmetnoj građi); e) popularnost (stripovi promoviraju pismenost i potiču mlade da postanu kritički konzumenti medijskih poruka); f) razvijanje analitičkih $i$ kritičkih vještina mišljenja.

Važnost primjene ilustrativnih tehnika poput umjetnosti stripa u podučavanju, prepoznavanju i verbaliziranju emotivnih stanja djece i mladih, u prevenciji problema mentalnog zdravlja i problema u ponašanju potvrđena je rezultatima raznih znanstvenih disciplina. Ako se problem promatra iz neurobiološkog aspekta (Ernst, 2009), nezrelost određenih mozgovnih struktura jedan je od razloga neprepoznavanja tuđih i vlastitih osjećaja, što se kao posljedica može manifestirati u neobazrivom i nepromišljenom ponašanju. Iz psihološkog aspekt možemo vidjeti kako su mladi fokusirani na ugodne emocije i kako ih želja za pobuđivanjem tih emocija može prisiliti na zanemarivanje posljedica određenih odluka i radnji (Wang, Hipp, Butts, Jose i Lakon, 2015). Potraga za uzbuđenjem može biti riskantna i opasna ako se izgubi osjećaj za granice i ugrozi vlastita ili tuđa dobrobit. Iz sociološkog aspekta razdoblje adolescencije karakterizirano je potrebom za druženjem s vršnjacima više nego ikad u životu (Claes, 1993). Ljudi će provesti velik dio svog života u svijetu skupine koju su osnovali i predvode vršnjaci. Stoga ih je važno upoznati, razumjeti i graditi odnos koji zahtijeva određenu emocionalnu kompetenciju. Podložnost vanjskim utjecajima koji nisu uvijek ugodni u današnjem modernom društvu često mlade ljude čini osjetljivima i nesigurnima (Steinberg, 2007). To su okolnosti na koje ponekad ne mogu utjecati, ali uvijek mogu odabrati kako se s njima nositi ako razviju dobru samokontrolu (Allard i Kesinger, 2013), pri čemu im umjetnost stripa zasigurno može pomoći.

Polje izražavanja osjećaja, raspoloženja i ideja je zanemareno i rijetko istraženo polje (Jolley, 2010, navedeno u Serjouie, 2012). Golomb i Whiteovo istraživanje (1992, navedeno u Serjouie, 2012) naglašava neke uzorke koji se pojavljuju u dječjim crtežima emotivnih stanja. U istraživanju koje je uključivalo 176 osnovnoškolaca, većina njih koristila se istim bojama kako bi izrazili sreću, tugu ili strah. Ali to nije bio slučaj samo s bojama, već i s oblikom. Emocije su najčešće izražavali pozicijom usana i obrva, i crtajući suze. Posebna je vrijednost u tome što mladi sami stvaraju stripove. Postaju 
aktivni stvaraoci i u isto vrijeme učenici i edukatori u polju emocionalnih stanja. Ako uzmemo u obzir ujedinjavanje koje postoji u dječjem likovnom izražavanju, možemo pretpostaviti kako će mladi bolje razumjeti pouke stripa ako strip stvore mladi. Ipak moramo naglasiti da su vrlo rijetke aktivnosti koje su s obrazovnog aspekta usmjerene podučavanju djece i mladih verbalnom izražavanju emotivnih svojstava određenih slika. Levie (1978, navedeno u Serjouie, 2012) naglašava kako je tumačenje slika također vještina koju treba naučiti i koja zahtijeva pomoć. Tumačenje slika kulturološki je uvjetovano. Charothers i Gardnerovo istraživanje (1979, navedeno u Serjouoie, 2012) pokazuje kako su dvanaestogodišnjaci sposobni prepoznati emocije na crtežima. Zbog toga je svrha ovog istraživanja usmjerena na procjenu načina na koji mladi vide svrhu i razumiju pouke materijala (stripova) koje su stvorili u sklopu projekta „Većinom sunčano”.

Iz svega je navedenog očita važnost stripova kao ekspresivne tehnike koja kombinira priču sa slikama, tj. likovnu i narativnu ekspresiju. Dodatno, stripovi se mogu koristiti kao tehnika projekcije jer omogućuju grupiranje iskustava koja je teško artikulirati u cjelinu, na način na koji ta iskustva prije nisu bila povezana (Porr i sur., 2011). Svrha je projektivne tehnike raditi na nefiltriranim (ponekad čak socijalno neprihvatljivim) percepcijama, osjećajima i željama. Lizey (1959, navedeno u Porr sur., 2011) navodi nekoliko vrsta projektivnih tehnika: asocijativne tehnike, tehnike nadopunjavanja, konstruktivne tehnike, tehnike odabira/reda i ekspresivne tehnike. Spomenute nam tehnike omogućavaju rad na izražavanju koji nije uobičajen u svakodnevnom radu ili razgovorima. Ako razmotrimo potencijal stripova kao projektivne tehnike, oni nam zaista omogućuju uključivanje iskustava u priču/roman na nov, još neispričan način. Stoga su stripovi asocijativna, konstruktivna i ekspresivna tehnika projekcije. Kada se koriste kao asocijativna tehnika, njihov je cilj predstaviti prvu/neposrednu asocijaciju; kao konstruktivna tehnika za cilj imaju stvaranje priče ili slika. Ako se koriste kao ekspresivna tehnika, onda je njihov cilj samoizražavanje zasnovano na određenom poticaju.

Budući da je fokus ove studije analiza stripa kao tehnike u radu s djecom i mladima, započet ćemo s pretpostavkom da ta kombinacija (asocijativne, konstruktivne i projektivne tehnike) može pomoći u prepoznavanju i verbalizaciji psiholoških stanja. Trenutna literatura o upotrebi ilustrativnih tehnika s djecom i mladima ukazuje na potencijalne koristi za djecu i mlade, primarno u prevenciji i tretmanu emocionalnih problema i problema u ponašanju. Zbog toga je glavni cilj ove studije potvrđivanje primjenjivosti stripa kao metode u programu čiji je cilj prepoznati i utvrditi vlastite i tuđe emocije. Zasnovana na tako postavljenom cilju, istraživačka su pitanja:

- Kako mladi razumiju sadržaj i pouke stripova?

- Je li strip koristan u prepoznavanju i utvrđivanju emocija, iz perspektive djece i adolescenata?

- Smatraju li djeca i adolescenti stripove korisnima za prepoznavanje vlastitih emocija? 


\section{Stvaranje stripa - opis projekta Većinom sunčano}

Institut za javno zdravstvo Splitsko-dalmatinske županije, Odsjek za mentalno zdravlje, u suradnji s Agencijom za znanost i obrazovanje, pokrenuo je projekt nazvan „Većinom sunčano”. Cilj projekta bio je stimuliranje emocionalnog razvoja, prepoznavanje vlastitih i tuđih emocija i poticanje izražavanja vlastitih osjećaja i potreba na razne društveno prihvatliive načine, koristeći se verbalizacijom prije nego uzrujanošću. Očekivani ishodi projekta bili su pozitivan utjecaj na školske ocjene, manji broj emocionalnih problema i smanjeno ovisničko i drugo rizično ponašanje tijekom daljeg razvoja mladih. Temi mentalnog zdravlja pristupilo se na zanimljiv, poznat i primjeren način, uz primjenu raznih medija za vlastito izražavanje (film, fotografija, pisanje, debatna skupina, umjetnička i dramska grupa, web-stranice; stvaranje, dizajn, priprema i tiskanje ishodišnih materijala). Projekt se sastojao od aktivnosti koje su primjerene za učenike osnovne i srednje škole i opću populaciju, ali također za djecu i mlade koji pripadaju rizičnoj skupini, poput onih u specifičnoj okolini, koji odrastaju izvan vlastitog doma.

Zamisao projektnog prijedloga, proceduralna i sadržajna primjena, započela je 2011. godine u obrazovnim institucijama i institucijama socijalne skrbi, a realizacija projekta još je u tijeku. Nakon faze pripreme i planiranja projekta, realizacija projekta počela je u akademskoj godini 2011./2012. i još je uvijek u tijeku, s kontinuiranim porastom u broju obrazovnih institucija i korisnika, uključene djece i adolescenata. Imajući na umu ciljeve projekta, tijekom nekoliko prethodnih godina održane su razne novinarske, literarne, likovne, dramske i računalne radionice, na kojima su učenici učili o emocionalnim i socijalnim vještinama prepoznavajući i kontrolirajući emocije, održavajući dobre odnose s drugima, donosili odgovorne odluke, sve sa svrhom sprečavanja nasilnog i suicidalnog ponašanja. Brojni su ishodi ovog projekta, stoga ćemo navesti samo neke od njih: Vodič o mentalnom zdravlju, zdravstveni kalendar naslovljen „Kada misli lutaju”, stvaranje i primjena obrazovne igre o emocijama itd. Zanimljivo je kako su sve ishodišne materijale napravila djeca i adolescenti, za djecu i adolescente, uz mentorstvo njihovih učitelja i školskih stručnih suradnika.

U ovom ćemo se radu usredotočiti na stvaranje i primjenu stripova, kao dijela ishodišnih materijala projekta, u poučavanju djece i adolescenata o emocijama. Prva faza projekta sastojala se od Škole stripa u akademskoj godini 2013./2014., u suradnji s Info zonom Split - koalicijom omladinskih organizacija u čijim su se prostorima održavale aktivnosti. Radionice su se održavale dva puta tjedno u razdoblju od šest mjeseci; vodili su ih akademski slikar Ivan Svaguša i psihologinja Janina Pavić, a sudionici su bili učenici iz škola projektnih partnera. Tijekom tog razdoblja učenici su naučili kako izraziti svoje ugodne i neugodne emocije na primjeren i društveno prihvatljiv način. Također su naučili kako izraziti određene emocije koristeći se raznim likovnim tehnikama. Kao rezultat tih radionica nastala su dva stripa: „Sjenke” i „Nevidljivi zid", a koje su stvorili i nacrtali sudionici uz mentorstvo tutora radionice. Stoga su učenici osmislili i napravili određene obrazovne materijale s ciljem njihove 
primjene u obrazovnim institucijama. U stvaranju ta dva stripa sudjelovala su 253 učenika.

Svaka vrsta umjetnosti predstavlja određenu vrstu komunikacije, što je također slučaj sa stripovima koji imaju za cilj poticanje osobnog angažmana čitatelja, posebno sudionika koji su prošli kroz niz autorefleksivnih vježbi tijekom kojih su razmišljali o neugodnim osjećajima o kojima je često teško razgovarati. U skladu s projektnim ciljem postavljen je poseban cilj za evaluaciju stvorenih stripova unutar projekta: evaluirati primjenjivost $u$ radu $s$ djecom i mladima u smislu pružanja pomoći pri procesu prepoznavanja i određivanja vlastitih i tuđih osjećaja, a što predstavlja drugu fazu realizacije projekta. Stripovi su se koristili kao kanal za ekspresiju emocija i za razgovor o problemima u ponašanju koji mogu komplicirati svakodnevno funkcioniranje djece i mladih ljudi, a koji će biti predstavljeni u nastavku rada.

\section{Metodologija}

\section{Sudionici}

Anketa je provedena među djecom i mladima uključenima u program, kako bi se odredilo u kojoj mjeri i na koji način materijali stvoreni na kreativnim radionicama u Školi umjetnosti stripa pomažu u prepoznavanju i određivanju vlastitih i tuđih emocija. Ciljana populacija bili su djeca i mladi koji su sudjelovali u programu „Većinom sunčano" 2014. godine. Tri skupine korisnika sudjelovale su u istraživanju: učenici petog i šestog razreda (231 učenik iz osnovne škola u Makarskoj i Žrnovici), učenici sedmog i osmog razreda (172 učenika osnovnih škola iz Splita, Stobreča, Žrnovice i Kaštela Starog), kao i srednjoškolci (96 učenika Medicinske srednje škole u Splitu), a što daje ukupan broj od 499 sudionika. Treba istaknuti da je projekt uključivao oko $16 \%$ mladih jer materijale vidjelo i njima se koristilo 3000 učenika.

\section{Sakupljanje podataka i opis varijabli}

Nakon sudjelovanja u projektu „Većinom sunčano”, sudionici su popunili upitnik o doživljaju projekta osmišljen zbog evaluacije učinkovitosti projekta. Upitnik se sastojao od četiri pitanja zatvorenog tipa (Sviđa li ti se ovaj način predstavljanja problema/teškoća mladih?; Smatraš li da je ovaj strip koristan?; Jesi li se poistovjetio/ la sa sadržajem stripa?; Misliš li da možeš izraziti svoje osjećaje na taj način?; Koju poruku su prema tvom mišljenju mladi, autori stripa, htjeli prenijeti ovim stripom?). Osim upitnika o istoj su temi sa sudionicima bile organizirane žarišne skupine. Intervjue i grupne razgovore provodili su stručni suradnici - psiholozi u navedenim školama. Djeca i mladi sudjelovali su u 35 žarišnih skupina tijekom svibnja, lipnja i rujna 2014. godine. U svakoj je skupini bilo 10 do 15 sudionika, a intervjui su trajali oko 45 minuta. Odgovori sudionika bili su zabilježeni tijekom žarišnih skupina, dajući materijal za analizu sadržaja. Ta kombinacija metoda sakupljanja podataka bila je primijenjena kako bi se, osim sakupljanja informacija od velikog broja sudionika, uspostavio indirektan kontakt između istraživača i sudionika. Spomenuto predstavlja 
važnu pretpostavku pristupa kvalitativnog istraživanja i može obogatiti sakupljanje kvantitativnih podataka (Milas, 2005)

\section{Metode obrade podataka}

Odgovori na pitanja zatvorenog tipa analizirani su na deskriptivnoj razini, a odgovori otvorenog tipa analizom u kojoj su odgovori sudionika predstavljali empirijski materijal, tj. sadržaj za analizu. Ti podatci obrađeni su analizom tematskog okvira koja predstavlja metodu utvrđivanja, analiziranja i izvješćivanja određenih uzoraka unutar podataka i može uključiti tumačenje raznih aspekata istraživačkih tema (Braun i Clarke, 2006). Analiza okvira omogućava usustavljivanje i pokretanje postupaka analize prema unaprijed uspostavljenom rasporedu. Odabrani princip analize podataka pri analizi tematskog okvira potječe od Lacey i Luff (2007). Sama metoda uključuje pet ključnih stadija (Lacey i Luff, 2007):

A Upoznavanje: cijeli ili djelomičan prijepis i čitanje podataka;

B Utvrđivanje tematskog okvira: to je početni okvir kodiranja razvijen iz već postojećih pitanja ili iz onih koja se javljaju u stadiju upoznavanja. Taj tematski okvir trebao bi se razvijati i rafinirati tijekom narednih stadija;

C Indeksiranje: Proces primjene tematskog okvira na podatke, koristeći se numeričkim ili tekstualnim kodovima za identifikaciju specifičnih podataka koji odgovaraju različitim temama (uobičajeniji naziv za taj proces u drugim pristupima kvalitativne analize je kodiranje);

D Izrada tablica - stvaranje tematskih tablica i prikaza slučajeva;

E Mapiranje i tumačenje: To znači traženje uzoraka, veza, koncepata i objašnjenja u podatcima.

Empirijska struktura podijeljena je prema školama koje sudionici pohađaju. Svi su odgovori kopirani u Word dokumentima, fontom Times New Roman, veličine 12, razmak 1. Na taj način stvorena je 321 stranica teksta, koji se potom koristio za analizu i odgovore na istraživačka pitanja.

Nadalje, koristeći se metodama uranjanja i kristalizacije (Borkan, 1999), utvrđen je teorijski okvir. Primijenjena su unaprijed definirana istraživačka pitanja. Sljedeći korak analize bio je označavanje i razvrstavanje tekstova svake skupine prema definiranim temama. Napravljena je tablica sažetka koja je sadržavala tri reda (za tri unaprijed definirane teme) i četiri stupca (teme, citati, bilješke i dojmovi, kodovi i uzorci). Tablica se koristila za tumačenje i prepoznavanje uzoraka putem kojih je moguće opisati definirane teme. Budući da su teme analize primarno definirane pitanjima koja su postavljana mladima, prvi je korak bio čitanje svake žarišne skupine, nakon čega su odgovorima dodani bilješka i dojmovi. Kodovi i uzorci koji su se koristili za opisivanje određenih tema bili su definirani na osnovi bilježaka i dojmova.

Važno je napomenuti da su prvi (upoznavanje s građom) i drugi korak u analizi (utvrđivanje tematskog okvira) zasnovani na neovisnom pristupu troje istraživača. Svaki od njih bio je upoznat s građom i dao prijedloge o temama. Na osnovi tih 
prijedloga, a imajući na umu cilj koji se nastoji postići, odabrane su tri teme (korisnost materijala, primjenjivost materijala, razumijevanje pouke stripa). Uslijedio je stadij indeksiranja i izrade tablica, što su izvela dva neovisna istraživača. Nakon ta dva stadija radili su zajedno na mapiranju i tumačenju. Na kraju su napisani izvještaj i analiza rezultata.

\section{Evaluacija rezultata projekta „Većinom sunčano" Deskriptivni rezultati}

Za analizu deskriptivnih rezultata koristit će se rezultati evaluacije (Tablica 1)

Tablica 1

Prezentacija rezultata evaluacije projekta „Većinom sunčano"

\begin{tabular}{lccccccccc}
\hline \multirow{2}{*}{ Pitanje } & \multicolumn{3}{c}{ Ne } & \multicolumn{3}{c}{ Djelomično } & \multicolumn{2}{c}{ Uglavnom da } & \multicolumn{2}{c}{ U potpunosti } \\
\cline { 2 - 10 } & $\mathrm{F}$ & $\%$ & $\mathrm{~F}$ & $\%$ & $\mathrm{~F}$ & $\%$ & $\mathrm{~F}$ & $\%$ \\
\hline $\begin{array}{l}\text { Sviđa li ti se ovaj način predstavljanja } \\
\text { problema/teškoća mladih? }\end{array}$ & 49 & 9,62 & 125 & 24,56 & 207 & 40,67 & 128 & 25,15 \\
Misliš li da je ovaj strip koristan i zašto? & 32 & 6,56 & 70 & 14,34 & 219 & 44,88 & 167 & 34,22 \\
Jesi li se poistovjetio/la sa stripom? & 195 & 39,24 & 176 & 35,41 & 86 & 17,30 & 40 & 8,05 \\
$\begin{array}{l}\text { Misliš li da bi mogao/la izraziti svoje } \\
\text { osjećaje na ovaj način? }\end{array}$ & 149 & 29,86 & 142 & 28,46 & 176 & 35,27 & 32 & 6,41 \\
\hline
\end{tabular}

Većina je sudionika odgovorila pozitivno na pitanje Sviđa li ti se ovakav način predstavljanja problema/teškoća mladih, a nešto manje od pola (40,6 \%) odgovorilo je uglavnom da; četvrtina je dala odgovor $u$ potpunosti. Ako dodamo četvrtinu onih kojima se djelomično sviđa takav način prezentiranja teškoća mladih, možemo zaključiti da više od devet desetina mladih ljudi djelomično ili u potpunosti ima pozitivne dojmove.

Odgovori o koristi stripova bili su većinom pozitivni. Poglavito, većina je sudionika $(93,44 \%)$ smatrala kako je strip barem djelomično koristan, a 44,88 \% sudionika odgovorilo je uglavnom da. 34,22\% sudionika reklo je u potpunosti, a 14,34 \% djelomično. Manje od jedne desetine sudionika (6,56 \%) nije smatralo da je strip koristan.

Ako u obzir uzmemo osobnu komponentu materijala, tj. kako mladi percipiraju osobnu korist stripa, zanimljivo je da se većina sudionika (39,24\%) ne poistovjećuje sa stripom, iako ga smatraju korisnim. Više od trećine sudionika djelomično se identificira sa stripom, a četvrtina izjavljuje da se s njim poistovjećuju uglavnom ili djelomično.

Većina je sudionika odgovorila na pitanje Misliš li da bi mogao/la izraziti svoje osjećaje na ovaj način odgovorom uglavnom da (35,27 \%). Zanimljivo je kako samo 6,41 \% sudionika izjavljuje da bi u potpunosti mogli izraziti svoje osjećaje na taj način. Kako su izjavili sami sudionici, neki od razloga mogli bi biti složenost doživljavanja određenih emocija, što ih čini teškim za izražavanje na taj način (Neki se osjećaji ne 
mogu izraziti ni primjenom riječi ni slika). Postotak onih koji ne bi mogli, ili bi samo djelomično mogli, izraziti svoje osjećaje na taj način gotovo je jednak i nešto manji od $30 \%$ za svaki odgovor. To je vjerojatno zbog činjenice da su neki sudionici našli druge načine izražavanja (Ponekad pišem pjesme. Pjesme o tome što mi se događa; Nisam baš naviknut/a na izražavanje emocija na ovaj način; Mogao/la bi, ali nisam sigurna kako reći ono o čemu razmišljam...).

\section{Tumačenje kvalitativnih podataka}

Slijedi analiza tematskog okvira tekstova stvorenih primjenom odgovora mladih na tri pitanja otvorenog tipa. Rezultati će biti predstavljeni u tri teme: korisnost materijala, primjenjivost materijala i razumijevanje pouka stripa.

\section{Percepcija korisnosti materijala}

Analizirajući prvu temu (korisnost materijala), utvrđeno je osam dimenzija: poticanje ljudi na razmišljanje o vlastitom ponašanju, poticanje na komunikaciju i izražavanje emocija i misli, poticanje na razmatranje i rješavanje problema mladih, poučavanje i prosljeđivanje informacija mladima na zabavan i pristupačan način, podizanje razine osviještenosti o raznolikosti među ljudima, osvješćivanje važnosti bliskih odnosa, umjetnička ekspresija kao sredstvo rješavanja psiholoških sukoba i strip kao medij identifikacije s projektom. Većina odgovora mladih pokazala je da strip smatraju korisnim, a manji broj sudionika misli da je strip nerazumljiv i beskoristan (Ne moraju svi razumjeti što je nacrtano; Mislim da ne može pomoći svakome).

Strip je motivirao neke sudionike na razmišljanje o vlastitom ponašanju i ponašanju ljudi oko sebe (Naučio nas je lijepom ponašanju; Može poučiti druge što da rade, a što ne; Pokazuje nam određene situacije i kako bismo se u njima trebali ponašati; Možemo naučiti više o vlastitom ponašanju). Sve nam to pokazuje da je strip naučio mlade razlici između poželjnog i nepoželjnog ponašanja, pokazao im kako se ponašati u određenim situacijama i istaknuo važnost dobrog ponašanja. Neki su od njih naveli da ih je potaknuo na emotivno otvaranje i puno lakše prihvaćanje neugodnih osjećaja, kao i da ih je ohrabrio da traže pomoć (Ljudi koji imaju probleme, strahove i nesigurnosti, kada čitaju stripove, mogu se nekome otvoriti, prihvatiti svoje strahove i pomoći svojim prijateljima). Pojedinci su izjavili kako strip smatraju korisnim jer ih je motivirao na druženje i potaknuo da budu vedri, otvoreni i pozitivni (Jer mladi mogu razmišljati o tome izoliraju li se ili su društveni. Pokušavaju li pobjeći od sebe ili prihvatiti sami sebe takvi kakvi jesu; Koristan je jer nas uči da budemo vedri, veseli i otvoreni; Potiče mlade ljude na više druženja s prijateljima; Da, jer se mnogi od naših vršnjaka izoliraju u zatvorenim prostorima s tehnologijom i ne puštaju druge unutra).

Druga dimenzija koju smo utvrdili tijekom analize jest poticanje ljudi na komunikaciju i izražavanje misli i emocija. Dio sudionika shvatio je kako ih je strip motivirao na komunikaciju i izražavanje emocija, što pokazuje da može biti edukativan na polju emocija (Jer ljudi trebaju naučiti izraziti svoje osjećaje; Jer je malo lakše razumjeti 
osjećaje; Da možemo izraziti svoje osjećaje; Važno je dijeliti osjećaje). Većina sudionika opisala je strip kao koristan jer ih ohrabruje na emotivno otvaranje (izražavanje misli i emocija), čak iako dio pokazuje sumnju prema kreativnom izričaju kao glavnoj metodi komunikacije s drugima (Mnoga su djeca naučila kako srušiti taj nevidljivi zid $i$ pokazati osjećaje na ovaj način; Jer nam pomaže s našim emocijama u ovom stadiju života; Mislim da je većinom koristan jer nam pokazuje kako izraziti osjećaje, ali ne mislim da je primaran način pokazivanja emocija; Djelomično nam pomaže da probudimo želju za razgovorom i razmišljanjem o vlastitim problemima, ali po mom mišljenju, nekad ne trebamo razne medije da nas potaknu na razgovor o vlastitim problemima. Ponekad stvari možemo riješiti sami). Ne samo da su mladi prepoznali važnost izražavanja emocija i osjećaja već su također bili potaknuti na razmišljanje o načinima rješavanja problema (Jer pomaže mladim ljudima da shvate kako nisu sami i da svatko ima svoje probleme s kojima se treba suočiti, a ne od njih bježati). Na osnovi njihovih odgovora vidi se kako su načini suočavanja s problemima i njihova predstavljanja primjereni njihovoj dobnoj skupini. To je vjerojatno jedan od razloga zbog kojeg su se mladi poistovjetili s problemom o kojem se raspravljalo, što je učinilo proces emotivnog otvaranja (izražavanja emocija i misli) puno lakšim (Da, jer problemi i teškoće su opisani na neobičan način, blizak mladim ljudima.). Taj ih je način izražavanja potaknuo na razmišljanje i pokazao im načine rješavanja problema (Pokazuje nam kako možemo riješiti probleme; Jer moramo razumjeti da se trebamo suočiti s našim problemima; Jer se bavi problemima koji se često pojavljuju među mladima; Počinjemo razmišljati o svojim problemima; Da, jer neki ljudi bježe od svojih problema, ali ih svejedno trebaju riješiti).

Strip je koristan zbog svog pristupa koji omogućava učenje na zabavan i poznat način (Mladi ljudi obično ne vole čitati duge i dosadne tekstove, ali ilustracije ih mogu motivirati na razmišljanje). Sudionici su istaknuli obrazovnu komponentu stripa, što ukazuje na njegovu učinkovitost (Možemo puno naučiti iz stripa; Jer je pragmatičan i može biti koristan u našim životima; Informativan je i zanimljiv te predstavlja oblik informiranja mladih; Jer je pragmatičan i govori nam više o osjećajima).

Jedan od ciljeva stripa bio je naglasiti raznolike pristupe emocijama, što su neki mladi prepoznali. U kontekstu razvijanja emocionalne kompetencije važan je čimbenik empatija koja omogućava prepoznavanje i prihvaćanje različitih načina izražavanja misli i emocija (Možemo vidjeti kako različiti ljudi izražavaju svoje osjećaje; Jer bi svatko trebao izraziti osjećaje na svoj način). Očito je kako je strip poslužio kao medij koji podiže razinu osviještenosti o postojanju raznolikosti i promovira njezino prihvaćanje. Kreativni izričaj može poslužiti kao poticaj za interakciju s onima kojima je teško verbalizirati vlastite emocije ( $D a$, jer ljudi koji ne razumiju riječi mogu razumjeti slike i emocije na slikama).

Rad na emocionalnoj kompetenciji vidljiv je u podizanju razine osviještenosti bliskih odnosa, što su priznali i sami sudionici. Razmišljajući o vlastitom ponašanju, vidjeli su posljedice lošeg ponašanja prema drugima, što ih je dodatno potaknulo u smislu njegovanja željenog ponašanja (Jer nas je motivirao da razmišljamo o ponašanju 
prema drugima). Može se reći da ih je strip poučio važnosti ljudskih odnosa, posebno prijateljstva (Pokazuje koristi prijateljstva; Pokazuje nam da su prijatelji važni).

Zbog činjenice da je umjetnost oblik komunikacije s čitateljem, može se reći da je upotreba drugog (ne samo verbalnog) kanala olakšala izražavanje emocija onih kojima to drugačije nije bilo lako. Umjetnička ekspresija poslužila je kao sredstvo za rješavanje psiholoških sukoba, smanjivanje napetosti, što se vidi u dogovorima sudionika ( $D a$, jer ljudi koji ne razumiju riječi mogu razumjeti slike i osjećaje na slikama). Taj kreativni oblik izražavanja misli i emocija poznat je onima koji se odabiru izraziti na ovaj način i onima koji se poistovjećuju s onim što je izraženo. Strip je poslužio kao medij za prenošenje dijela njihovih problema na glavni lik, koji ih uspijeva uspješno riješiti putem priče (Olakšava ljudske probleme samo jer ga čitaju, jer su u istoj situaciji; Prepoznali smo vlastite probleme u ovom stripu; Pomaže jer smo u istim situacijama; Može pokazati mladima kako njihovi problemi nisu nerješivi; Ponekad nismo svjesni vlastitih ili tudih problema, pa bi stripovi poput ovoga trebali pomoći ljudima da shvate kako nisu sami; Svi mi imamo svoje probleme ili predrasude koje trebamo naučiti riješiti). Mladi su opisali strip kao koristan jer vjeruju kako se pojedinci u sličnim situacijama mogu potaknuti na preuzimanje inicijative pri rješavanju vlastitih problema (Mislim da je ovaj strip odličan jer govori o svakodnevnim problemima s kojima se svatko može poistovjetiti; Jer netko tko pročita strip može biti u istoj situaciji i pokušati se suočiti sa svojim problemima).

\section{Percepcija primjenjivosti materijala}

Druga tema definirana za tematsku analizu jest percepcija primjenjivosti materijala, stoga su analizirani odgovori na pitanje Smatraš li kako bi mogao/la izraziti svoje osjećaje na ovaj način. U tematskoj analizi stvoreno je šest dimenzija: prepoznavanje važnosti izražavanja emocija, prepoznavanje važnosti bavljenja problemima, poticanje ljudi na upotrebu vizualnih metoda izričaja i komunikacije, isticanje potrebe za dijeljenjem i međusobnim pomaganjem, terapeutski elementi stripova kao interaktivnog medija, poistovjećivanje s projektom putem stripova. Tako navedene dimenzije bit će detaljnije objašnjene u nastavku rada.

Razmatrajući pitanje percepcije primjenjivosti materijala, malen broj sudionika izrazio je sumnju u vlastitu sposobnost izražavanja emocija putem vizualnog medija. Oni smatraju kako bi se lakše izrazili na drugačiji način (Nisam ljubitelj stripova, draže su mi knjige $i$ više volim izražavati emocije riječima nego slikama jer ne vidim smisao toga; Ne mogu se izraziti na ovaj način; Za mene je teško izraziti se upotrebom crteža; Ja ne izražavam svoje osjećaje na ovaj način. Ne možete zapravo vidjeti moje osjećaje; Svoje osjećaje pokazujem jednoj osobi kojoj vjerujem). Neki mladi naveli su strah kao kontraefekt (Jer možemo rastužiti druge) i manjak želje da se povjere i komuniciraju (Jer većinom ne želim da drugi znaju kako se osjećam; Radije bi svoje probleme riješio/la sama i zadržala ih za sebe; Ne osjećam se ugodno kada izražavam osjećaje na bilo koji način...), unatoč tomu što su bili spremni pokušati u slučaju kada su mislili da bi pomoglo 
nekom drugom (Ne volim pričati o svojim osjećajima, osim s najboljim prijateljem. Kad bi znala da bi nekome pomoglo, vjerojatno bi imala hrabrosti napraviti strip).

Većina je sudionika prepoznala važnost izražavanja emocija i ustvrdila da je strip to umnogome olakšao i omogućio im da to učine na zanimljiv način (Jer lakše možemo izraziti osjećaje, na mirniji način; Jer je ovo dobar način izražavanja emocija; Jer je lako izraziti osjećaje koristeći olovku i papir; Jer je to najbolji i najlakši način izražavanja osjećaja). Ne samo da ih uči važnosti izražavanja emocija već ih također potiče na to da to čine na socijalno prihvatljiv način (Jer me nije strah izraziti svoje osjećaje $i$ ne bježim od njih; Da, jer kada sam sretna dijelim svoju sreću s drugima). Kao sredstvo izražavanja emocija crteži su prisutni u svim kulturama i putem njih se mogu izraziti univerzalne emocije (Jer ih svatko tko ima emocije razumije, čak u stripu bez teksta, $i$ može ih izraziti jer ih svi razumiju).

Primjenjivost materijala također je utvrđena u priznavanju važnosti suočavanja s problemima, što je jedan sudionik istaknuo izražavajući želju da se suoči sa svojim problemima koristeći se tom vrstom medija (Jer također imam neke probleme $i$ želio bi ih izraziti kroz strip). U ovom kontekstu također možemo prepoznati važnost stripova kao sredstva artikuliranja unutarnjih stanja i mogućnost njihove upotrebe u procesu razvijanja emocionalne kompetencije. Mladi su sudionici prihvatili kreativnu (posebno vizualnu) metodu izražavanja i komunikacije i istaknuli neke od njezinih prednosti (Kada sam tužan i imam probleme, možda bi mogao pokušati; Zato što je zabavno pokazati to kroz strip umjesto knjigu, što je dosadno; Lakše je tako, kada rasporedim sve na papiru i vidim što me muči, više i nije tako strašno), ali također i neke od nedostataka koji su povezani uz činjenicu da se neke emocije ne mogu izraziti na ovaj način ( $U$ nekim bi situacijama mogao/la. Sreću, tugu i ljutnju bi mogao izraziti, ali neki su osjećaji previše složeni da bi se izrazili na ovaj način). Važnost stripa također se očituje u potrebi za dijeljenjem misli i emocija i međusobnom pomoći, što su sudionici izrazili nakon čitanja stripa. Neki mladi ljudi istaknuli su kako ih je strip nadahnuo da izraze emocije i komuniciraju o svojim teškoćama te traže pomoć i zaista zažele tu pomoć ( Jer ako ih izrazimo, neće ostati u nama; Jer nam drugi mogu pomoći; Jer ću biti sposobna pokazati drugima što osjećam; Jer ću se osjećati bolje kada nekome kažem što osjećam; Jer želim podijeliti s drugima neke stvari; $D a$, jer želim pomoći svojim vršnjacima i odraslima da sruše zidove; Jer uvijek pomažem i želim biti u društvu izoliranih ljudi, želim srušiti taj „zid”).

Terapeutski elementi stripa kao interaktivnog medija također se mogu vidjeti u dogovorima sudionika koji su naglasili smirujući učinak koji je imao na njih (Slike $i$ boje pomažu, pokazuju duboke emocije i pomažu da se smirimo; Mnogo je lakše izraziti se kroz umjetnost. Mnogi možda neće prepoznati tvoje osjećaje, ali ti ćeš se osjećati bolje). Također, neki se sudionici na taj način lakše nose s emocijama poput tuge, ljutnje i tjeskobe (Jer, kada sam tužan/na, odem u svoju sobu i crtam; Jer nije loše i sve izbacimo; Jer kada sam ljut/a i loše raspoložena, uzmem papir i bojim).

Neki su se sudionici poistovjetili s glavnim likovima stripa, što im je olakšalo bavljenje određenim emocijama prikazanim u stripu, a predstavlja jedan od razloga 
zašto su mladi ljudi prihvatili strip i smatrali ga primjerenim (Jer sam sve to doživio; Da, jer se u tim situacijama osjećam isto; Jer se i ja nekad osjećam kao da ne pripadam).

\section{Razumijevanje pouka stripova}

Treća je tema vezana uz razumijevanje pouka stripova. U analizi je prepoznato šest dimenzija (suočavanjes vlastitim osjećajima; naglašavanje važnosti odnosa; naglašavanje važnosti komunikacije; promocija prihvaćanja različitosti među ljudima; promicanje razvoja i pozitivnog stava prema životu; poticanje ljudi na prihvaćanje pomoći). Putem njihovih odgovora na pitanje Koju poruku autori stripa nisu htjeli poslati mladi su većinom pokazali razumijevanje u skladu s idejom koju su autori stripa imali pri njegovu stvaranju.

Neki od njih došli su do zaključka kako su autori stripa govorili da se trebamo suočiti sa svojim problemima i osjećajima, a ne bježati od njih, pri čemu je važnost određivanja i prilagodbe naglašena, kao i vrsta neovisnosti u bavljenju s teškoćama (Htjeli su nas naučiti kako biti odlučni i nikada ne odustati; Da se trebamo baviti problemima i brigama; ne sakrivati se u četiri zida, već družiti s prijateljima; Ako se ništa ne promijeni, mi se trebamo mijenjati; Ne trebamo odustati od svijeta i naših ciljeva; Ponekad trebamo doživjeti neuspjeh kako bi postali jači i odlučniji u postizanju naših ciljeva). Mladi sudionici prepoznali su poruku potrebe za suočavanjem s vlastitim emocijama i strahovima (Htjeli su nam reći da ne bježimo od sebe; Strah od neuspjeha nije uspjeh, neuspjeh je kada odustanemo od pokušaja da uspijemo.). Sudionici su također prepoznali poruku vezanu uz važnost uspostavljanja bliskih veza s ljudima. Njihovi odgovori pokazuju da su prepoznali važnost primjerenog stava prema emocijama i problemima, kao i važnost ulaganja u bliske odnose (Ponekad se možeš naljutiti, ali ne iskaljuj se na prijateljima; Htjeli su ti reći da trebaš uložiti napor i zakoračiti naprijed, poštivati svoje prijatelje i pokušati biti dobar ako si bio/la nepristojna). Također su istaknuli ulogu emotivne potpore kao čimbenika u izgradnji i održavanju bliskih odnosa (Trebaš se potruditi za prijateljstvo jer je to jedna od najvrjednijih stvari; kada ti netko želi pomoći, to je vrlo lijepo).

Neki sudionici spomenuli su komunikaciju kao jednu od metoda podjele emocija i problema. Naglasili su važnost dijeljenja emocija i misli te prepoznali činjenicu kako su autori istaknuli raznolike načine pristupanja emocijama (Mali autori željeli su reći da možeš osloboditi svoje osjećaje; Htjeli su da znamo kako nas naši strahovi, naša nesposobnost otvaranja, često koči. Ako se nekome povjerimo i prihvatimo pomoć, bit ćemo sposobni nadvladati naše strahove). Također su prepoznali poruku prihvaćanja raznolikosti među ljudima, posebno kada se radi o različitim načinima izražavanja emocija (Htjeli su reći da svatko izražava emocije na svoj način; Nije u redu ismijavati bilo koga; Poštuj druge.).

Mladi sudionici također smatraju kako strip promovira razvoj pozitivnog stava prema životu, što uključuje prihvaćanje svijeta onakvim kakav jest, sa svim teškoćama koje nosi. Vide ulogu percipiranja tih problema kao ključnu (Kada prihvatimo vlastite probleme, dan će biti sunčaniji). Možemo reći da je strip poticajan u smislu motiviranja 
ljudi na iznalaženje rješenja i bavljenje problemima (Mislim da su nam htjeli pokazati da možemo riješiti bilo što; Željeli su da usvojimo pozitivan stav prema svijetu, poticali nas na pronalaženje rješenja, razgovor o emocijama i suočavanje s vlastitim strahovima). Shvatili su da jedino prihvaćanjem samih sebe možemo doživjeti istinsku ljepotu života u svom sjaju (Trebamo se fokusirati na bolje sutra i prihvatiti se kakvi jesmo, sa svim vrlinama i manama; Moramo se opustiti, srušiti zidove i jednostavno otpustiti stege i onda ćemo biti bolji za sebe i svoju okolinu).

Putem svojih odgovora mladi su ljudi naglasili važnost prihvaćanja pomoći i njezina davanja drugima kada je potrebno (Ne trebamo biti grubi prema drugima $i$ trebamo ponuditi pomoć; Uvijek trebamo prihvatiti pomoć jer nije lako sam se nositi s problemima; Unatoč našoj sposobnosti rješavanja problema, pomoć je uvijek dobrodošla; Kada prihvatimo nečiju pomoć, znat ćemo kada i kako pomoći sebi i drugima. Percepcija je različita, druga strana svijeta je ljepša, sjene su prihvatlive, pomozi drugima, jednostavno). Uočili su važnost tolerancije, emocionalne potpore i prihvaćanja pomoći kao ključnih čimbenika u procesu prihvaćanja samih sebe.

\section{Rasprava o rezultatima}

Kvantitativni i kvalitativni rezultati pokazuju koherentnost percepcije analiziranih materijala (stripa), što nije iznenađujuće. Velik je uspjeh činjenica da kvalitativni rezultati objašnjavaju osnovne kvantitativne rezultate, drugim riječima, omogućuju objašnjenje i dublji uvid. Ako promotrimo opće dojmove mladih vezane uz materijale, vidimo da mladi percipiraju predstavljene materijale pozitivno, bilo djelomično ili u potpunosti. Ta činjenica vezana je uz odobrenje te vrste predstavljanja problema i korisnost stvorenog materijala (stripa). Nadalje, kvantitativni pokazatelji govore da percepcija osobne primjenjivosti materijala i opći pozitivan dojam nisu koherentni. Malen postotak mladih iskazao je kako se poistovjećuju sa stripom, da bi mogao biti „njihov" način rada na prepoznavanju i izražavanju emocija. Kvalitativni podatci omogućuju nam da primijetimo veću važnost tih općih pokazatelja. Dimenzije utvrđene analizom tematskog okvira mogu se redom koristiti za donošenje zaključka o općem pozitivnom dojmu i o tome kako mladi uviđaju primjenjivost materijala (Tablica 2). Utvrđene dimenzije predstavljene su na razini općih dojmova i na osobnoj razini, kako bi se utvrdila osobna korist koju mladi ljudi prepoznaju u radu na stripu.

Ako promotrimo utvrđene dimenzije na razini tematske analize, očito je da mladi opisuju dobre strane i prepoznaju korist materijala na dvije razine. Na općoj razini mladi opisuju korist rada na tim materijalima. Možemo pretpostaviti kako prepoznaju procese koji su se zbivali tijekom rada na materijalima. Također su govorili o potencijalima stripa na općoj razini njegove primjenjivosti u radu s mladima. Prepoznaju i kako bi strip općenito mogao biti koristan u obrazovanju ljudi kada je riječ o emocionalnom aspektu, kako bi mogao poticati socijalizaciju, razgovor i otvaranje, kako je zabavan medij i može biti sredstvo rješavanja problema. Osim tog općeg dojma, mladi opisuju i druge dobiti od rada na tim materijalima (stripu). 
Naglašavaju kako im je strip pomogao da steknu uvid u raznolikost percipiranja i izražavanja emocija, u važnost odnosa i prijateljstva u rješavanju problema i činjenicu da nisu jedini koji imaju probleme. Iako smatraju da strip može potaknuti ljude na emotivno otvaranje, neki mladi ipak izražavaju oklijevanje prema kreativnom izričaju kao glavnoj metodi komunikacije s drugima. Kada razmatramo njihove odgovore na pitanje kako strip može poslužiti kao medij za otvaranje, razgovor i učenje o emocijama, ne smiju se zanemariti drugi aspekti nužni za rad na emocijama (sigurno okruženje, povjerenje između članova grupe). To je razlog zašto dvodimenzionalnost odgovora ne iznenađuje, s obzirom na to da se sve odvijalo u učionici gdje je obrazovna sastavnica uvelike prisutna. Ipak, važno je napomenuti i mogućnosti koje mladi prepoznaju ako je okolina drugačija i sigurnija, ona s više povjerenja i orijentirana prema rješavanju emocionalnih problema.

Tablica 2

Dimenzije dobivene na razini tematske analize

\begin{tabular}{|c|c|c|c|}
\hline \multirow{2}{*}{$\begin{array}{c}\text { Razina } \\
\text { percepcije }\end{array}$} & \multicolumn{3}{|c|}{ Teme } \\
\hline & $\begin{array}{l}\text { Percepcija korisnosti } \\
\text { materijala }\end{array}$ & $\begin{array}{l}\text { Percepcija primjenjivosti } \\
\text { materijala }\end{array}$ & $\begin{array}{c}\text { Razumijevanje pouka } \\
\text { stripova }\end{array}$ \\
\hline 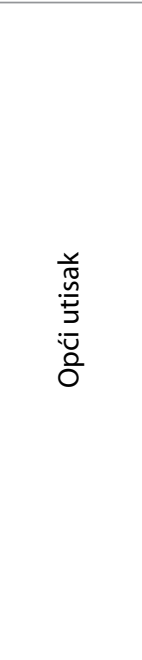 & $\begin{array}{l}\text { Poticanje ljudi na } \\
\text { komunikaciju i } \\
\text { izražavanje misli i } \\
\text { emocija } \\
\text { Poticanje ljudi } \\
\text { na razmišljanje i } \\
\text { pronalaženje načina } \\
\text { rješavanja problema } \\
\text { mladih } \\
\text { Obrazovanje i } \\
\text { prenošenje informacija } \\
\text { na način koji je zabavan } \\
\text { i blizak mladima } \\
\text { Umjetničko izražavanje } \\
\text { kao sredstvo rješavanja } \\
\text { psiholoških sukoba } \\
\text { Umjetnost stripa kao } \\
\text { medij poistovjećivanja s } \\
\text { projektom }\end{array}$ & $\begin{array}{l}\text { Poticanje ljudi na } \\
\text { upotrebu vizualnih } \\
\text { sredstava komunikacije } \\
\text { i ekspresije } \\
\text { Terapeutski element } \\
\text { stripa kao interaktivnog } \\
\text { medija }\end{array}$ & $\begin{array}{l}\text { Suočavanje s vlastitim } \\
\text { emocijama } \\
\text { Isticanje vrijednosti } \\
\text { odnosa } \\
\text { Isticanje važnosti } \\
\text { komunikacije } \\
\text { Poticanje ljudi } \\
\text { na prihvaćanje } \\
\text { međusobnih razlika } \\
\text { Poticanje razvoja } \\
\text { pozitivnog stava } \\
\text { prema životu }\end{array}$ \\
\hline 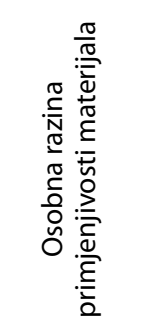 & $\begin{array}{l}\text { Poticanje ljudi na } \\
\text { razmatranje vlastitog } \\
\text { ponašanja } \\
\text { Podizanje razine } \\
\text { osviještenosti o važnost } \\
\text { bliskih odnosa } \\
\text { Obrazovanje ljudi o } \\
\text { našim međusobnim } \\
\text { razlikama }\end{array}$ & $\begin{array}{l}\text { Prepoznavanje važnosti } \\
\text { izražavanja emocija } \\
\text { Prepoznavanje važnosti } \\
\text { suočavanja s problemima } \\
\text { Naglašavanje potrebe } \\
\text { za dijeljenjem i } \\
\text { međusobnom pomoći } \\
\text { Poistovjećivanje s } \\
\text { projektom putem stripa }\end{array}$ & $\begin{array}{l}\text { Ohrabrivanje ljudi na } \\
\text { prihvaćanje pomoći }\end{array}$ \\
\hline
\end{tabular}

U odnosu na percepciju korisnosti materijala mladi su primarno izrazili svoje mišljenje o tome je li umjetnička ekspresija i ilustracija njihov način izražavanja 
emocija. U slučaju da smatraju umjetničku ekspresiju i projektivne tehnike svojom metodom izražavanja emocija, ističu prednosti upotrebe stripa, posebno u emotivnoj sferi, u slučajevima kada žele izraziti neugodne emocije poput tuge, ljutnje ili tjeskobe. Oni vide kako je takav način izražavanja emocija, što je lakše uz pomoć stripa, društveno prihvatljiv i omogućava im da se počnu suočavati s problemima, komunicirati o teškoćama i tražiti pomoć. Također su izjavili kako su radom na stripu prepoznali svoju vlastitu želju da pomognu drugima. Na njihovu percepciju primjenjivosti materijala također je utjecao proces poistovjećivanja s glavnim likovima. Ipak, ako mladi smatraju da strip nije primjeren medij za izražavanje emocija, onda obično prepoznaju njegovu općenitu korisnost u radu s mladim, ali ne za sebe osobno. Ti nas odgovori upozoravaju na moguće izazove upotrebe te vrste medija; neki smatraju kako bi bilo teško izraziti emocije upotrebom vizualnih medija i kako postoje negativni utjecaji te metode rada ako nema povjerenja između članova grupe. Ti odgovori također pokazuju koliko je važno stvoriti sigurno okruženje pri radu na prepoznavanju emocija i imati više mogućnosti u određenim situacijama. S druge strane, taj medij omogućava nam da podučimo mlade kako pomoći drugima.

Treće problemsko pitanje odnosilo se na percepciju pouke stripa mladih. Način na koji su doživjeli pouku stripa usklađen je s osobnom i općom koristi koju su prepoznali kroz prve dvije teme analize, što nije iznenađujuće. Zato je moguće povezati opće dimenzije u trećoj temi s ciljem projekta i svrhom stripova. Zbog činjenice da je cilj ovog projekta bio potaknuti emocionalni razvoj, prepoznati osobne i tuđe emocije i izraziti ih na društveno prihvatljiv način, isti cilj može se vidjeti u razumijevanju pouka stripa. Kada se radi o emotivnom razvoju, mladi su prepoznali kako je svrha stripa podići razinu osviještenosti o tome kako se s problemima i osjećajima treba suočiti, a ne bježati od njih. Važno je primijetiti da strip može biti sredstvo komunikacije o emocijama i problemima koje imamo i želimo riješiti. Idući cilj bio je povezan $\mathrm{s}$ prepoznavanjem vlastitih i tuđih emocija. Dokaz da je taj cilj ostvaren, jest u činjenici da mladi prepoznaju pouke stripa o svom osobnom razvoju i razvoju odnosa. $\mathrm{Na}$ osobnoj razini možemo razlikovati poruku koja promovira pozitivan stav prema životu i svim raznolikim teškoćama koje nosi. Na razini izgradnje odnosa mladi su smatrali kako im strip govori o tome koliko je važno povezati se s ljudima i uspostaviti bliske odnose, prihvatiti i ponuditi drugima pomoć i prihvatiti različitosti u načinima izražavanja emocionalnih stanja. Sa svim dobitima analiza pokazuje kako je strip primjerena tehnika za socioemocionalno obrazovanje djece i mladih.

Uzimajući u obzir koristi koje su mladi stekli sudjelovanjem u aktivnostima stripa, potencijali te tehnike su očiti. Ključno je istaknuti kako su tu tehniku mladi općenito dobro prihvatili. Strip smatraju primjerenom i zanimljivom metodom rada. U kontekstu dimenzija utvrđenih putem raznih tematskih analiza, jasno je da doživljavaju strip kao tehniku koja im omogućava prepoznavanje osobnih emocija, verbalizaciju neugodnih emocija, prihvaćanje pomoći drugih i pružanje pomoći, izgradnju bliskih odnosa i prihvaćanje različitosti među ljudima u njihovim načinima 
izražavanja emocija. Mladi koji nisu percipirali strip na pozitivan način, ključan su izvor informacija za stvaranje budućih aktivnosti upotrebe tog medija. Iako je određeni broj mladih naveo kako umjetnička ekspresija nije njihova preferirana metoda bavljenja emocijama, nisu zanemarili činjenicu kako je preduvjet za tu vrstu rada stvaranje sigurne i povjerljive okoline. To bi trebalo imati na umu pri planiranju daljih aktivnosti upotrebe te tehnike jer osim primjene tih ili sličnih ilustrativnih tehnika nužno je pripremiti skupinu za rad na stripovima stvarajući ugodnu atmosferu, uspostavljajući povjerenje između članova skupine u kojoj će se osjećati slobodnima izraziti emocije, podučiti ih kako dati pomoć i podršku u teškim trenutcima i pokazati razumijevanje. To se može postići podučavanjem mladih komunikacijskim vještinama poput empatičnog slušanja, asertivne ekspresije osobnih potreba i prihvaćanja različitosti. Ta vrsta sigurnog grupnog okoliša omogućila bi otkrivanje i istraživanje vlastite jedinstvenosti, što predstavlja vrlo važan razvojni zadatak u adolescenciji (McFerran-Skewes, 2004). Kako bi ti procesi doprinijeli pozitivnom razvoju mentalnog zdravlja, važan je sklad između vlastitih percepcija i povratne informacije drugih. Budući da je proces usklađivanja tuđih poruka s vlastitom slikom o sebi riskantan, posebno za mlade koji ne preferiraju verbalnu ekspresiju, ilustrativne tehnike imaju veliku važnost u tom procesu samootkrivanja i primanja povratnih informacija okoline. Osim toga, stripovi su materijali koje djeca čitaju s jednakom učinkovitošću (Sones, 1944), što ih čini izvrsnim medijem za djecu i mlade koji pokazuju određene rizike u polju obrazovanja poput loših ocjena, specifičnih teškoća u čitanju ili pisanju i nedostatka motivacije za stjecanjem određenog znanja.

Vrijednost rezultata ovog projekta odnosi se na sposobnost mladih da razumiju poruke koje su mladi prenijeli stripom. Zbog činjenice da je način na koji su ti mladi autori predstavili emocionalna stanja prilično sličan i primjeren dobi, možemo pretpostaviti kako su mladi najbolji autori za tu vrstu teksta i slike. Čitanje stripa može nam potencijalno omogućiti projekciju na likove stripa, što je preduvjet za autentičnu ekspresiju u kontekstu grupe.

\section{Zaključak}

U sigurnoj okolini, $\mathrm{u}$ dobro strukturiranom grupnom radu, proizvod ovog projekta (strip) može imati dvije prednosti - lako se njime koristiti jer je kratak i pun događaja te omogućava sudionicima grupnog programa zajednički rad na onome što su doživjeli, što inicira razvojne procese poput emocionalne pismenosti ili integracije poruka o sebi.

Djeca i mladi trebaju sigurnu obrazovnu okolinu u kojoj mogu izraziti emocije i o njima učiti. Škola i drugo osoblje u institucijama u kojima korisnici projekta žive mogu poticati i podržavati taj aspekt osobnog rasta putem interaktivne aktivnosti kontinuiranog rada. $U$ ovom istraživanju mladi su posebno naglasili važnost sigurnog okruženja za rad na ekspresivnim tehnikama poput stripa.

Kombinacija likovnosti (slike) i naracije (teksta) olakšava djeci i mladima pričanje o vlastitim osjećajima i problemima s kojima su suočeni. Neki su sudionici bili potaknuti 
na razmišljanje o emocionalnim, a neki o bihevioralnim komponentama. Osim toga, sudionici su prepoznali korist stripa ne samo za sebe nego i za svoje vršnjake. Mogu slati razne poruke koristeći se stripom (podići razinu osviještenosti o razlikama između ljudi, naglasiti važnost bliskih odnosa); ova im metoda izražavanja može olakšati rješavanje određenih psiholoških sukoba i transfer njihovih osobnih problema na glavne likove, koji ih uspješno rješavaju promovirajući samopomoć tijekom procesa poistovjećivanja.

Unatoč činjenici da su stripovi laka i s ljubavlju prihvaćena radna tehnika među mladima, rijetko se izrađuju i koriste u toj populaciji. Stoga su te spoznaje važne iako još uvijek trebamo biti svjesni njihovih metodoloških ograničenja. Kako bi evaluirali izravne dobiti rada na stripovima kao obrazovnim materijalima, važno je planirati dalju implementaciju projekta i procjenu postignuća. U skladu s tim daljnji je plan evaluirati potencijalne promjene u populaciji mladih sudionika pri radu na materijalima, s ciljem ocjenjivanja primjenjivosti i korisnosti materijala. Ovo je način na koji možemo prevladati ograničenja rezultata do sada, a koji nam daju opći dojam većeg broja mladih. Dobivanje detaljnih uvida u promjene unutar ciljane populacije dat će nove dimenzije informacija o ovoj tehnici. Promatrajući sve navedeno, očito je kako je projekt „Većinom sunčano” koristan i kako je ključno nastavljanje njegove realizacije te uključivanje većeg broja korisnika iz raznih škola i okolina. Važno je podići razinu osviještenosti i promovirati važnost razvoja mentalnog zdravlja djece i mladih uz pomoć lokalne zajednice i medija. 


\section{Prilog}

Protokol za analizu tematskog okvira

\begin{tabular}{|c|c|c|c|}
\hline Teme & $\begin{array}{l}\text { Učenici osnovne i srednje } \\
\text { škole (originalni odgovori) }\end{array}$ & $\begin{array}{l}\text { Bilješke i } \\
\text { dojmovi }\end{array}$ & Dimenzije \\
\hline $\begin{array}{l}\text { Percepcija } \\
\text { korisnosti } \\
\text { materijala }\end{array}$ & $\begin{array}{l}\text { Potiče mlade da se više } \\
\text { druže s prijateljima. }\end{array}$ & $\begin{array}{l}\text { Potiče } \\
\text { socijalizaciju }\end{array}$ & $\begin{array}{l}\text { Poticanje ljudi } \\
\text { na razmišljanje o } \\
\text { vlastitom ponašanju }\end{array}$ \\
\hline $\begin{array}{l}\text { Percepcija } \\
\text { korisnosti } \\
\text { materijala }\end{array}$ & $\begin{array}{l}\text { U stripu prepoznajemo } \\
\text { svoje probleme. }\end{array}$ & $\begin{array}{l}\text { Dopušta ti } \\
\text { poistovjećivanje s } \\
\text { problemima }\end{array}$ & $\begin{array}{l}\text { Strip kao medij } \\
\text { poistovjećivanja s } \\
\text { projektom }\end{array}$ \\
\hline $\begin{array}{l}\text { Percepcija } \\
\text { primjenjivosti } \\
\text { (Omogućuje } \\
\text { li izražavanje } \\
\text { osjećaja) }\end{array}$ & $\begin{array}{l}\text { Jer kad sam tužan, odem u } \\
\text { svoju sobu i počnem crtati. }\end{array}$ & $\begin{array}{l}\text { Olakšava } \\
\text { izražavanje } \\
\text { neugodnih } \\
\text { osjećaja }\end{array}$ & $\begin{array}{l}\text { Terapeutski } \\
\text { elementi stripa } \\
\text { kao interaktivnog } \\
\text { medija }\end{array}$ \\
\hline $\begin{array}{l}\text { Percepcija } \\
\text { primjenjivosti } \\
\text { (Omogućuje } \\
\text { li izražavanje } \\
\text { osjećaja?) }\end{array}$ & $\begin{array}{l}\text { Jer svatko tko ima osjećaje } \\
\text { može ih prepoznati u stripu, } \\
\text { čak bez riječi, i može ih } \\
\text { izraziti jer svatko razumije } \\
\text { osjećaje. }\end{array}$ & $\begin{array}{l}\text { Crteži kao } \\
\text { sredstvo } \\
\text { prikazivanja } \\
\text { univerzalnog }\end{array}$ & $\begin{array}{l}\text { Prepoznavanje } \\
\text { važnosti izražavanja } \\
\text { emocija }\end{array}$ \\
\hline $\begin{array}{l}\text { Razumijevanje } \\
\text { pouke stripova }\end{array}$ & Poštuj druge. & $\begin{array}{l}\text { Uči te poštivati } \\
\text { druge. }\end{array}$ & $\begin{array}{l}\text { Promocija } \\
\text { prihvaćanja } \\
\text { različitosti među } \\
\text { ljudima }\end{array}$ \\
\hline $\begin{array}{l}\text { Razumijevanje } \\
\text { pouke stripova }\end{array}$ & $\begin{array}{l}\text { Život nije uvijek savršen, ali } \\
\text { s tim se možemo nositi. }\end{array}$ & $\begin{array}{l}\text { Trebamo se nositi } \\
\text { sa svim s čim smo } \\
\text { suočeni }\end{array}$ & $\begin{array}{l}\text { Promocija razvoja } \\
\text { pozitivnog stava } \\
\text { prema životu }\end{array}$ \\
\hline
\end{tabular}

